\title{
A complex unit for a complex disease: the HCM-Family Unit
}

\author{
Olga Vriz', Hani AlSergani ${ }^{1}$, Ahmed Nahid Elshaer ${ }^{2}$, Abdullah Shaik², Ali Hassan Mushtaq ${ }^{2}$, \\ Michele Lioncino $^{3}$, Bandar Alamro ${ }^{1}$, Emanuele Monda ${ }^{3}$, Martina Caiazza ${ }^{3}$, Giuseppe Russo ${ }^{4}$, \\ Ciro Mauro ${ }^{4}$, Eduardo Bossone ${ }^{4}$, Zuhair N Al-Hassnan ${ }^{5}$, Dimpna Albert-Brotons ${ }^{1}$, Giuseppe Limongelli ${ }^{3}$ \\ ${ }^{1}$ Department of Cardiology, King Faisal Specialist Hospital and Research Center, Riyadh, Saudi Arabia; ${ }^{2}$ AlFaisal \\ University, School of Medicine, Riyadh, Saudi Arabia; ${ }^{3}$ Inherited and Rare Cardiovascular Disease Unit, \\ Department of Translational Medical Sciences, University of Campania "Luigi Vanvitelli", AORN dei Colli, Monaldi \\ Hospital, Naples, Italy; ${ }^{4}$ Department of Cardiology, Cardarelli Hospital, Naples, Italy; ${ }^{5}$ Cardiovascular Genetics \\ Program and Department of Medical Genetics, King Faisal Specialist Hospital and Research Centre, Riyadh, \\ Saudi Arabia
}

\begin{abstract}
Hypertrophic cardiomyopathy (HCM) is a group of heterogeneous disorders that are most commonly passed on in a heritable
\end{abstract}

Correspondence: Prof. Olga Vriz, Heart Centre, King Faisal Specialist Hospital and Research Centre, Zahrawi St., Al Maather, Riyadh 12713, Saudi Arabia.

Tel. +96.611464-7272; extension 32056. Fax: +96.6114427791.

E-mail: olgavriz@yahoo.com

Key words: Hypertrophic cardiomyopathy; genetics; hypertrophic cardiomyopathy unit.

Contributions: All the authors made a substantive intellectual contribution. OV, ANE, AS, AHM, ML, MC, manuscript drafting; all authors edited and revised the manuscript, read and approved the final version of the manuscript and agreed to be accountable for all aspects of the work.

Conflict of interest: The authors declare that they have no competing interests, and all authors confirm accuracy.

Ethical approval: This study has been approved by the Ethical Committee at King Faisal Specialist Hospital and Research Center, Riyadh, Saudi Arabia.

Received for publication: 14 November 2021.

Accepted for publication: 30 November 2021.

Publisher's note: All claims expressed in this article are solely those of the authors and do not necessarily represent those of their affiliated organizations, or those of the publisher, the editors and the reviewers. Any product that may be evaluated in this article or claim that may be made by its manufacturer is not guaranteed or endorsed by the publisher.

${ }^{\circ}$ Copyright: the Author(s), 2021

Licensee PAGEPress, Italy

Monaldi Archives for Chest Disease 2022; 92:2147

doi: 10.4081/monaldi.2021.2147

This article is distributed under the terms of the Creative Commons Attribution-NonCommercial International License (CC BY-NC 4.0) which permits any noncommercial use, distribution, and reproduction in any medium, provided the original author(s) and source are credited. manner. It is a relatively rare disease around the globe, but due to increased rates of consanguinity within the Kingdom of Saudi Arabia, we speculate a high incidence of undiagnosed cases. The aim of this paper is to elucidate a systematic approach in dealing with HCM patients and since HCM has variable presentation, we have summarized differentials for diagnosis and how different subtypes and genes can have an impact on the clinical picture, management and prognosis. Moreover, we propose a referral multi-disciplinary team HCM-Family Unit in Saudi Arabia and an integrated role in a network between King Faisal Hospital and Inherited and Rare Cardiovascular Disease Unit-Monaldi Hospital, Italy (among the 24 excellence centers of the European Reference Network (ERN) GUARD-Heart).

\section{Introduction}

Hypertrophic cardiomyopathy (HCM), defined as an increase in left ventricular (LV) wall thickness that cannot be solely explained by abnormal loading conditions, is associated with myocardial and electrical dysfunction [1]. The diagnosis, both in obstructive and non-obstructive form, requires the absence of other cardiovascular disease capable of producing equivalent hypertrophy [2].

The estimated prevalence of HCM is 1 in 500 coming based on echocardiographic imaging. However, with the advent of advanced imaging modalities and genetic testing, the incidence raised to 1 in 200 accounting the combined prevalence of phenotypically expressed HCM as well as genetic carriers $[3,4]$. Therefore, it has been estimated that HCM affects around 20 million people, making this disease the most common genetic cardiovascular disease [5]. Although HCM seems less prevalent among women, both sexes are equally affected [6].

This review presents a systematic approach to the definition, assessment, management and prognosis of patients affected by HCM and their relatives based on current scientific evidence and guidelines. Additionally, the aim is also to describe the organization and the peculiar healthcare model of our HCM-Family Unit in Saudi Arabia and the international multidisciplinary cooperation between King Faisal Specialist Hospital and Research Center and Monaldi Hospital. 


\section{HCM-Family Unit: a new healthcare model for complex and heterogeneous patients}

HCM is a genetic disease with different etiologies according to age and clinical presentation. Different etiologies mean also different management, and possibly treatments. Moreover, the morpho-functional phenotype (i.e., degree of hypertrophy, fibrosis, outflow tract obstruction, diastolic and/or systolic dysfunction) requires careful investigations and evaluation for possible management. It is clear that a dedicated unit needs specific characteristics, including: i) pediatric and/or adult cardiologists with a specific expertise in diagnosis and management of cardiomyopathies; ii) a multidisciplinary team, for the diagnosis and management of systemic diseases associated with cardiomyopathies; iii) a family-based approach and a transition model between pediatric and adult HCM patients. On this ground, our HCM-Family Unit, though handled by cardiologists, is a multidisciplinary team requiring different professional roles, including cardiac surgeons, cardiac pediatrics, geneticists, psychologists, neurologists and metabolism experts. A peculiarity of our Unit will be the high prevalence of rare cardiomyopathies, made possible by the high rates of consanguinity in Saudi Arabia. This also requires a Specialized link with a highly experience Cardiomyopathy team. Herein, we propose the first example of "HCM-Extended Family Unit" made possible by a collaboration network between King Faisal Hospital and Inherited and Rare Cardiovascular Disease Unit-Monaldi Hospital, Italy (among the 24 excellence centers of the European reference Network (ERN) GUARD-Heart). The Saudi-Italian collaboration will be founded on a shared program of care (i.e., teleconsultation), research (i.e., registries, protocols, etc.), and education (i.e., consultant and junior doctors exchange, meetings), (Figure 1).

The HCM-Family Unit will manage complex cases with diagnosis and treatment challenges and, by completing the "learning curve" in the near future, will be also a referral Consultation Unit/Teleconsultation for peripheral non-specialized centers, where the stratified patients will be sent back for routine follow-up [2].

\section{Definition and etiology}

In adult patients, the definition of HCM is based on left ventricular wall thickness $\geq 15 \mathrm{~mm}$ in any segment (from base to apex, ensuring thickness is recorded at mitral, mid-LV and apical levels). However genetic and non-genetic disorders can present with HCM with a wall thickness between $13-14 \mathrm{~mm}$; in such cases, diagnosis is contingent upon further evaluation [2,7]. In children, diagnostic criteria of HCM have to be adjusted for body surface area [2], and a cut off of a LV wall thickness greater than 2.5 standard deviation than the predicted mean ( $\mathrm{z}$-score $>2$ ) at any segment of left ventricle is wildly accepted [7]. Up to $60 \%$ of adult HCM patients shows evidence of autosomal dominant transmission caused by sarcomere protein mutations. However, a subgroup of patients with non-familial HCM, defined by the absence of an overt family history of HCM (non-familial HCM) and a negative genetic testing for sarcomere causative mutations, seems to have better event-free survival and a more benign clinical course [8].

$\mathrm{HCM}$ can be challenging to diagnose as there are many diseases with similar presentations known as "HCM Phenocopies" or secondary causes of left ventricular hypertrophy that can have a

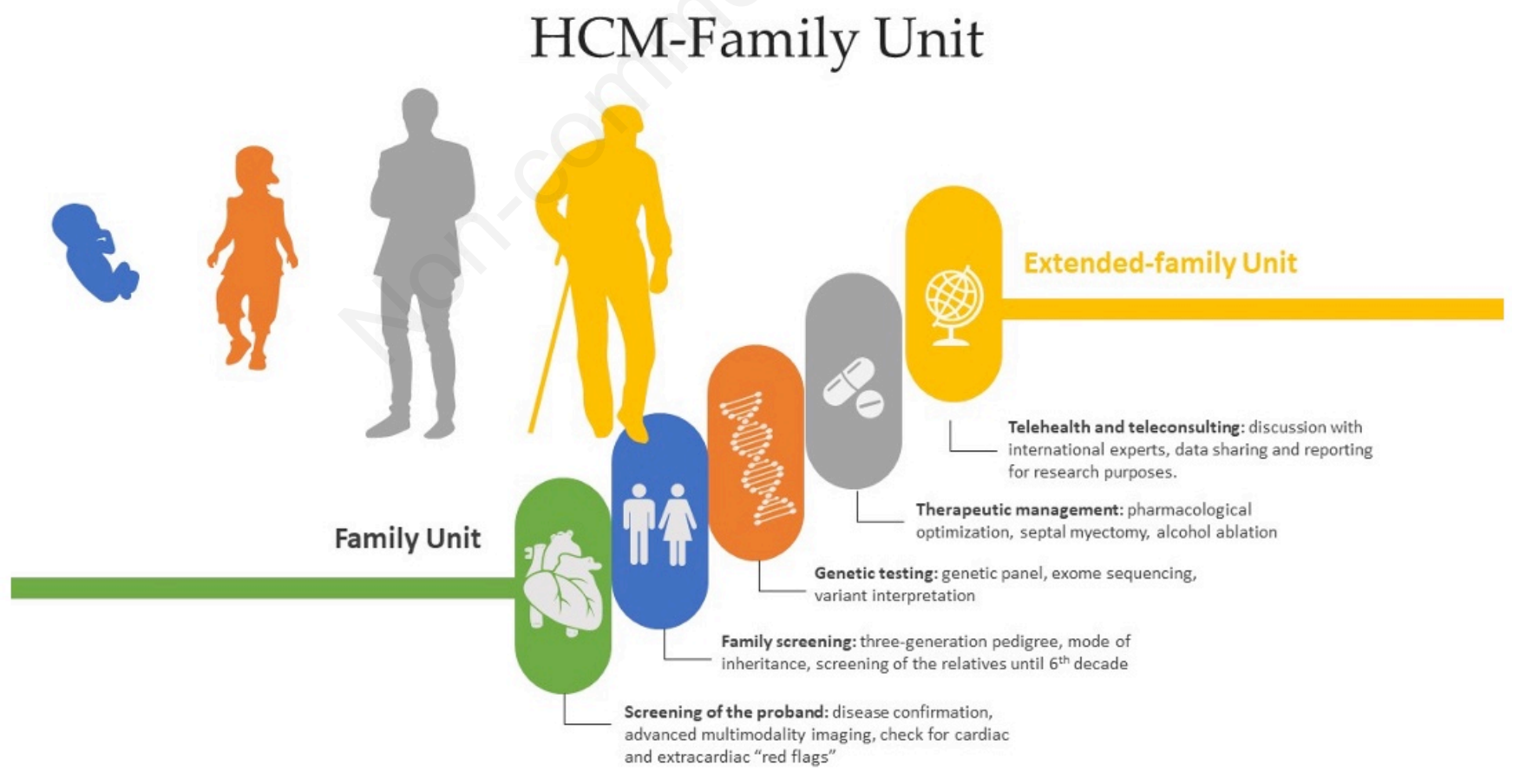

Figure 1. Graphical abstract. The HCM-Family Unit is a multidisciplinary unit, responsible for patient care from neonatal to adultelderly age. The Unit screens the proband and family by pedigree and genetic testing, and defines risk stratification and therapeutic approach. The HCM-Family Unit is part of an international network of experts to share complex cases and knowledge and will organize a national network for local counseling. Ultimately, the HCM-Family Unit is meant to be a referral Unit for clinical, research and teaching activity. 
similar presentation, yet a different etiology and age-specific presentation [9-12]. The identification of clinical clues ("red flags") which could raise the suspicion of non-sarcomeric variants should be systematically performed in order to orient the best therapeutic approach.

\section{HCM-Family Unit organization}

Probands and their relatives, who are at risk of developing HCM, are evaluated at the HCM-Family Unit starting from the confirmation, risk stratification and management of therapeutic options (Table 1, Figure 2). Because of age-specific penetrance of sarcomeric mutation, childhood-onset HCM is a more heterogeneous group and, although sarcomeric mutations still represent $-60 \%$ of the cases according to recent data from the Sarcomeric Human Cardiomyopathy Registry (SHaRe) [13], other causes of non-sarcomeric HCM should be excluded. In particular, differential diagnosis should include inherited errors of metabolism (i.e., glycogen storage diseases (GSDs), lysosomal storage diseases, fatty acid oxidation disorders), neuromuscular diseases, malformation syndromes (i.e., RASopathies), and mitochondrial diseases [13,14]. To have information either from the proband or from the family is determinant for the final diagnosis. Since the disease is relatively rare, positive genetic studies varies between 20 to $90 \%$ depending on the disease and is frequently difficult to find a genotype-phenotype correlation. For this reason, national and international registries, particularly when shared among international HCM-com- prehensive units, both with co-segregation and functional studies, may help to achieve a correct diagnosis [15].

\section{Probands and relatives referred to the HCM-Family Unit}

Most patients with HCM are asymptomatic and they are usually identified during incidental ECG screening or if 2D echocardiography is performed for other reasons.

Many pathophysiological mechanisms may contribute to cause symptoms in HCM patients. The main characteristics are left ventricular outflow tract (LVOTO) obstruction and impaired diastolic function, which may contribute to the elevation in LV filling pressures [16]. Atrial dilatation, which is a consequence of impaired diastole, predisposes HCM patients to higher risk of atrial fibrillation and supraventricular arrhythmias $[17,18]$. Furthermore, patients affected by HCM may show mitral valve abnormalities, and often show elongated anterior mitral leaflet or chordae tendineae or papillary muscles abnormalities. Mitral regurgitation can be frequently detected among HCM patients and represents a marker of complexity, particularly in patients who should undergo septal myectomy. The imbalance between oxygen supply and demand causes myocardial ischemia and may account for chest pain as initial presentation. Furthermore, can be involved in the pathophysiology of apical aneurysm which is characterized by the fibrotic substitution of the apical myocardium and be responsible of major arrhythmias, syncope and sudden

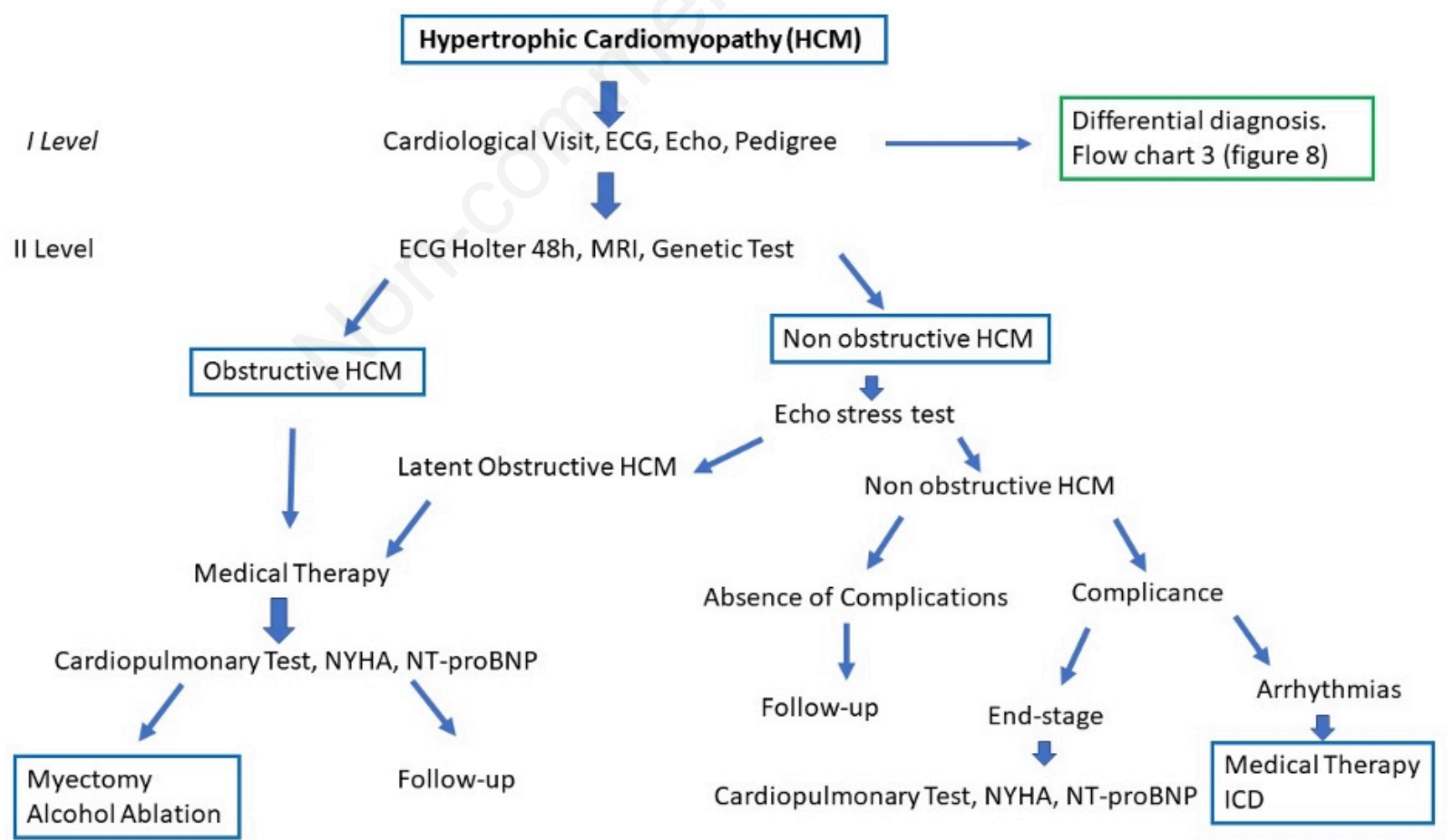

Figure 2. Flow chart for the management of patients at risk of developing HCM. ECG, electrocardiogram; HCM, hypertrophic cardiomyopathy; MRI, magnetic resonance imaging; NT-proBNP, N-terminal pro brain natriuretic peptide; NYHA, New York Heart Association. 
death, thrombus formation and ischemic events [19]. HCM patients with apical aneurysm have 3-fold greater adverse event than HCM without apical aneurysm [20]. Also, myocardial bridging has high prevalence in HCM and can be the cause of chest pain, arrhythmia, syncope and sudden death. (Table 1) [7,16,19,21-35]. First degree relative should undergo regular screening (cardiology visit, ECG, echocardiography, pedigree and genetic test, etc.). If a pathogenic variant is detected in the proband, first-degree relatives with positive genetic test will be followed at the HCM-Family Unit [36]. In case of pathogenic or likely pathogenic variants, the absence of the mutation in a firstdegree relative excludes the patient from subsequent follow up. If the mutation is a variant of uncertain significance (VUS), as the result is not clinically actionable, regular screening has to be performed until 40-50 [7,36]. Moreover, in cases of VUS, co-segregation studies in the family should be performed and, if associated with positive phenotype, this VUS gene could be the reason of the pathology (Figure 3).

Patients carrying sarcomere variants may have different phenotypes within the same family. In other words, a broad phenotypic spectrum could be associated to the same sarcomere mutation (i.e., restrictive cardiomyopathy or dilated cardiomyopathy, noncompaction cardiomyopathy and $\mathrm{HCM}$ ) and recurrent patterns of disease progression have been studied (Figure 4) [37,38]. Moreover phenotype overlap can coexist and "restrictive phenotype" could be part of the continuum spectrum of HCM [39]. Variant in genes MYH7, TNNI3, MYL2 associated with HCM can show the restrictive phenotype [40].

\section{Pedigree/genetics}

A pedigree represents the distribution of a specific disease in a family and in the case of HCM at least three generations should be included during the evaluation to identify the possible inheritance pattern [41]. Family screening should occur regardless of age. After the first evaluation, first-degree family members should undergo regular follow-up, depending on disease severity. A family study should be conducted to look for the pathogenic mutation that was found in the proband and the relatives should be screened as soon as possible. An autosomal dominant mode of transmission, as the case of HCM, each offspring of an affected family has $50 \%$ chance to be affected and the age at which the disease become manifest within each individual is quite variable. In the case of consanguinity, quite frequent in Saudi Arabia, auto-

Table 1. Diagnostic approach and most common findings in hypertrophic cardiomyopathy patients.

\section{Clinical criteria}

Cardiac symptoms

$\begin{array}{ll}\text { Physical examination } & \text { Musculoskeletal involvement, dysmorphic features, and other organ system involvement } \\ \text { Split S2 sound due to delayed closure of the aortic valve [16] }\end{array}$

\section{Diagnostic criteria}

Lab tests

ECG

48-hour Holter ECG

Transthoracic echocardiography

Genetic test

Genetic test

Pedigree

Exercise stress echocardiography

MRI

CT

Hemoglobin, renal function, liver transaminases, creatinine phosphokinase, plasma/leukocyte alpha galactosidase A, serum immunoglobulin light chain, fating glucose, NT-proBNP, thyroid function, plasma lactate [7] Dyspnea, postprandial breathlessness (common), orthopnea and paroxysmal nocturnal dyspnea (rare) [23] Chest pain [24]

History of syncope, palpitation, arrhythmias related to LVOTO exercise intolerance, dizziness

Family history of SCD, cardiomyopathies, exercise intolerance, implantable cardioverter-defibrillators, multisystem diseases, and recurrent syncope [25]

Split S2 sound due to delayed closure of the aortic valve [16

Normal in less severe HCM phenotype

Signs of LVH and repolarization abnormalities are the most common findings, pathological Q-waves, left-axis deviation, left atrial dilation [26,27]

Atrial and ventricular arrythmias (AF up to 50\%, NSVT, PVCs, conduction abnormalities) $[7,28,29]$

All LV segments from apex to base have to be measured [30,31]

Two-thirds of patients have LVOTO induced by physical effort or Valsalva maneuver [17,21,22]

Apical aneurysm

LVEF is usually preserved, GLS is an accurate parameter of systolic function [32]

Proband and family

History of at least three generations

In symptomatic patients if bedside maneuvers fail to induce LVOTO $>50 \mathrm{mmHg}$

Particular useful for apical and antero-lateral wall involvement. Myocardial fibrosis in $65 \%$ of patients [23-25]

Diffuse and extensive late gadolinium enhancement quantified or estimated by visual inspection, comprising $15 \%$ of LV mass is now considered an established risk factor for sudden death [2,19]

CT with contrast provides accurate measurements of ventricular thickness, volume, ejection fraction and mass [26,27]. CT detects anomalous coronary arteries, which is the second most common cause of SCD at 17\%, right behind HCM at $36 \%[22,33-35]$

Endomyocardial biopsy $\quad$ Not part of the routine diagnostic workup. Performed when myocardial infiltration or storage disease is suspected Myocyte hypertrophy, myocardial disarray, interstitial fibrosis

MRI, cardiac magnetic resonance; CT, computed tomography; ECG, electrocardiogram; GLS, global longitudinal strain; HCM, hypertrophic cardiomyopathy; LV, left ventricular; LVEF, left ventricular ejection fraction; LVH, left ventricular hypertrophy; LVOTO, left ventricular outflow tract obstruction; NT-proBNP, N-terminal pro brain natriuretic peptide; AF, atrial fibrillation; NSVT, non-sustained ventricular tachycardia; PVC, premature ventricular complex; SCD, cardiac sudden death. 


\section{FAMILY MEMBERS OUTPATIENTS CLINIC}

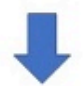

I LEVEL

II-III LEVEL

\section{yes}

\section{Cardiological Visit, ECG, Echo, Pedigree}

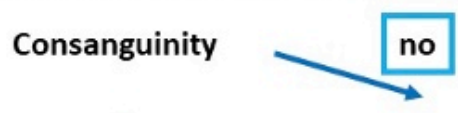

ECG Holter, Genetic Test

CMP. Genetic+

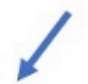

Echo stress test, MRI

CMPs outpatients Clinic

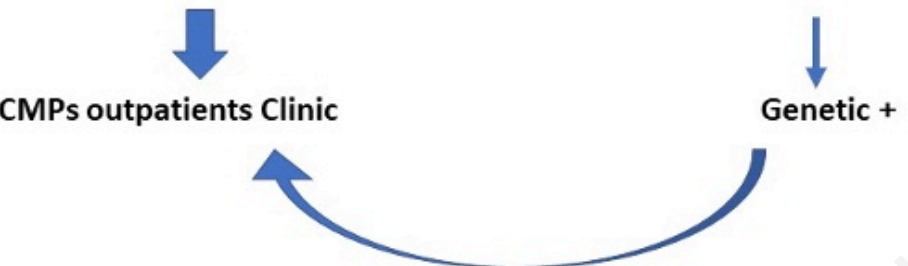

No Genetics,

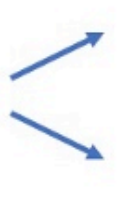

First Degree Relatives and siblings

Figure 3. Flow chart for the management of family members. CMP, cardiomyopathy; ECG, electrocardiogram; HCM, hypertrophic cardiomyopathy; MRI, magnetic resonance imaging.
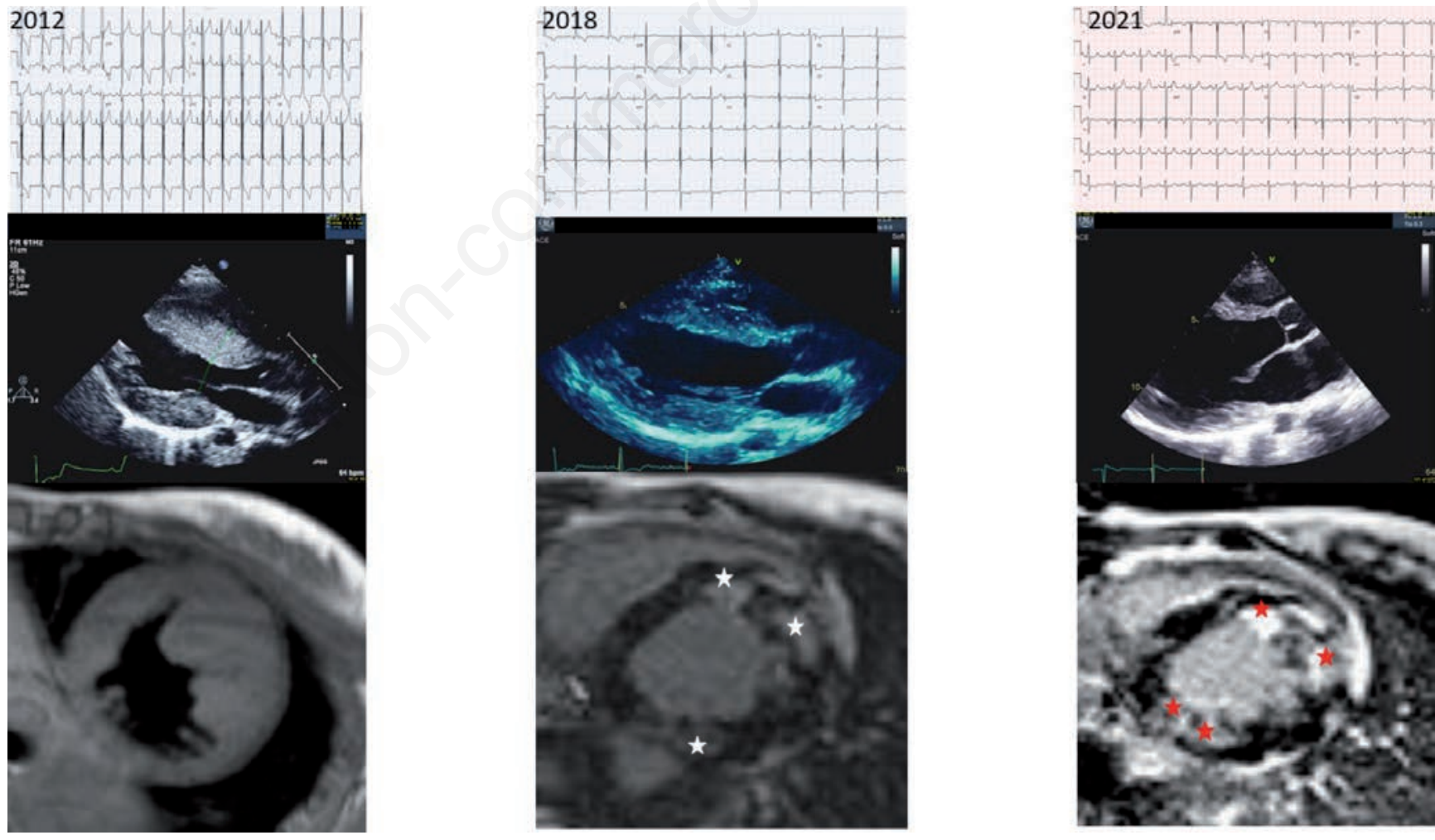

Figure 4. Evolution from HCM to dilated cardiomyopathy. Patients with hypertrophic cardiomyopathy evolved to dilated cardiomyopathy after 10 years. 2012: Severe asymmetric hypertrophy. 2018: Diffuse patchy fibrosis, non-ischemic pattern, consistent with nonobstructive hypertrophic cardiomyopathy. 2021: Abnormal dyskinetic ventricular wall motion abnormalities. Eccentric hypertrophy with abnormal trabeculations on the apical and lateral wall segments. Fibrosis at the ventricular septum at right ventricular insertion sites. Stars indicate fibrosis at MRI. 
somal recessive inheritance is more likely and each descendent has a $25 \%$ chance of inheriting two mutated alleles (Figure 5). A mutation can sometimes appear de novo in the proband with no involvement of the family but could still be transmitted to any descendent [42].

Moreover, HCM presents with variable expressivity with incomplete penetrance $[43,44]$ and may coexist with other forms of cardiomyopathy. Extensive molecular screening of sarcomere genes has been conducted in the past 25 years, discovering more than 1400 mutations associated with HCM [45]. The majority of the disease-causing variants occur in myosin heavy chain (MYH2) and myosin binding protein C (MYBPC3) [44]. On aggregate, $60 \%$ of patients with positive family history of HCM and $40 \%$ of sporadic cases of HCM tend to have mutations in the sarcomere proteins. Furthermore, clinical and genetic studies have uncovered the relatively uncommon role of pathogenic variants in other sarcomere protein genes [46]. In a small minority of cases, HCM is caused by mutations in non-sarcomere genes [44]. For example, recently a research group described in Saudi Arabia a cluster of 16 families with homozygous c450T $>\mathrm{C}$ (p.Phe154Leu) in ELAC2 gene, characterized by poor outcome in pediatric age and presenting with either form of HCM or dilated cardiomyopathy (Table 2) [14,47-92]. The genetic approach is a stepwise genetic testing. Blood samples are sent to a core lab with patient information, phenotype and pedigree. The panel includes the 36 genes most commonly associated with familial forms of HCM with a probability to detect the disease close to $60 \%$. If mutation is not identified, analysis is extended to exome/ whole genome to cover genes that are either implicated in an overlapping phenotype or could be involved in a similar pathway but not strongly clinically implicated. Sometimes the genetic study cannot identify the genetic mutation responsible of the disease because not all the genes involved in the phenotype can be studied and/or there are some cases $(5 \%$, identified in members of small families) that exhibit two (digenic) or more (oligogenic) causal mutations in the same gene or causal mutations in different genes [93-95]. The severity of ventricular hypertrophy in these patients is more pronounced. It is important to underline that not to find the mutation, does not mean that there is no disease.

The European Society of Human Genetics recommend not to perform genetic testing in children before the age of 10. In Middle East and in particular in Saudi Arabia, the high incidence of consanguinity makes genetic as first line in the diagnostic protocol of $\mathrm{HCM}$, particularly in children [96].

\section{Phenocopies}

Some infiltrative and storage diseases may present as phenocopies of HCM according to morphology, ventricular function and maximum interventricular wall thickness is $>15 \mathrm{~mm}$ [7]. Unmasking the underlying disease and looking beyond the ventricular morphology and function, is of paramount importance in order to define prognosis, guide reproductive choices, and specific therapy to the patient. Age of onset is among the factors to consider for differential diagnosis given that glycogen storage diseases are more common in infants, whereas wild-type transthyretin amyloidosis (ATTRwt) is common in advanced age (predominantly men over the age of 65 years) or Fabry disease in adult patients [911,97,98] (Table 3; Figures 6 and 7).

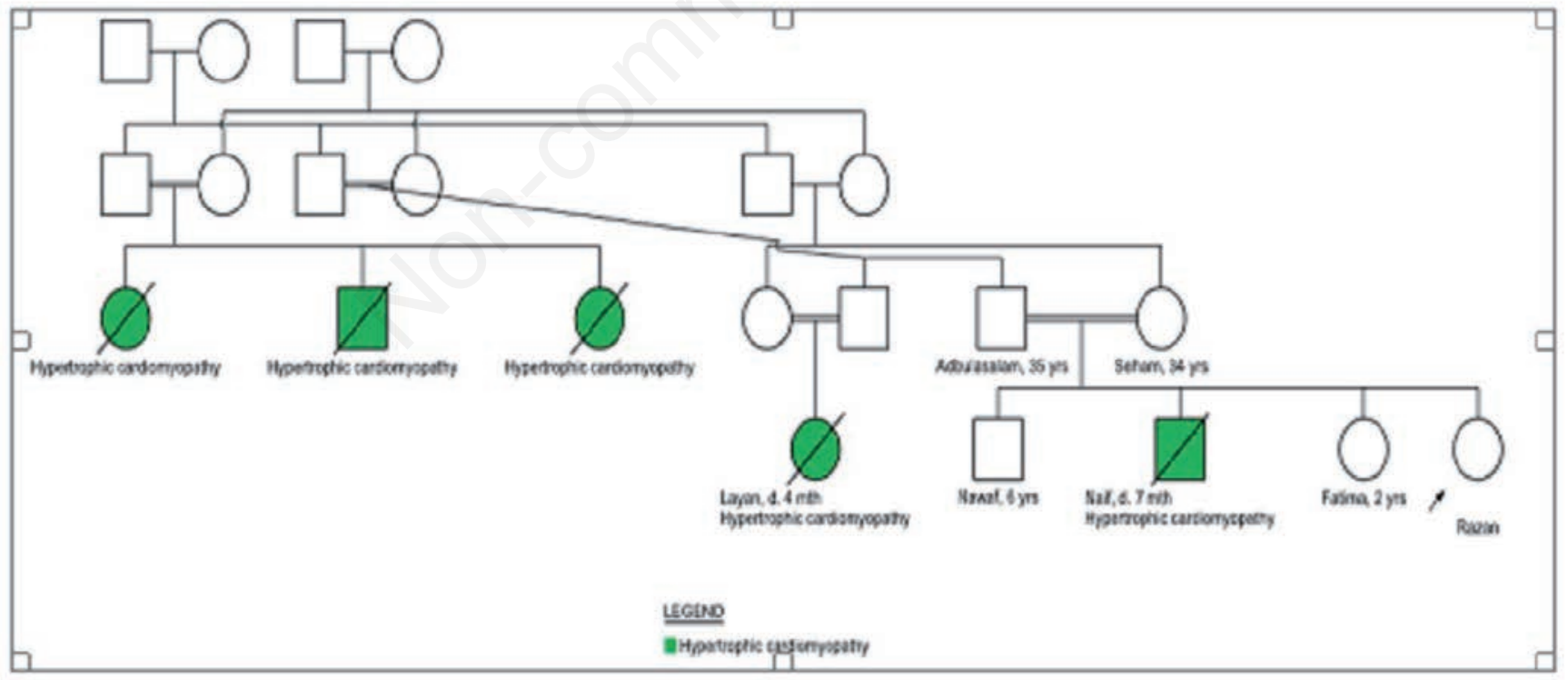
Parents are $2^{\text {nd }}$ degree relatives
History of death for $\mathrm{HCM}$

\section{Mutation: ELAC2 c.460T>C:p.Phe154Leu}

Figure 5. Example of a pedigree. 
Table 2. Most common genes involved and phenotype expression.

\begin{tabular}{|c|c|c|}
\hline Sarcomeric genes & Clinical features & Prognosis \\
\hline Myosin heavy chain (MYH7) [32] & $\begin{array}{l}\text { Presents at younger age [48], HCM, weakness of } \\
\text { distal muscles, and foot deformities [49] }\end{array}$ & Poor prognosis [50] \\
\hline Myosin binding protein C (MYBPC3) [32] & $\begin{array}{l}\text { HCM, syncope, dyspnea, chest pain, and elevated blood } \\
\text { pressure [48] }\end{array}$ & $\begin{array}{l}\text { Good prognosis before age } 40 \text { years/favorable } \\
\text { prognosis [48] }\end{array}$ \\
\hline Troponin T (TNNT2) & $\begin{array}{l}\text { HCM, high incidence of SCD, slow disease progression } \\
\text { of HCM, low incidence of SCD without hypertrophy [51] }\end{array}$ & Poor outcome [51] \\
\hline Troponin I (TNNI3) & $\begin{array}{l}\text { HCM, severe and early onset [52], high incidence of SCD } \\
\text { despite mild hypertrophy often in children [53] } \\
\text { (low incidence of restrictive cardiomyopathy) }\end{array}$ & Poor prognosis [52] \\
\hline$\alpha$-tropomyosin (TPM1) & HCM, left ventricular dysfunction and SCD & Poor prognosis [54] \\
\hline Myosin regulatory light chain 2 (MYL2) & HCM, SCD usually in the early age [55] & Good prognosis [56] \\
\hline Myosin essential light chain (MYL3) & $\begin{array}{l}\text { Mainly adult onset HCM, SCD at a young age [57], } \\
\text { mid-left ventricular chamber type hypertrophy [58] }\end{array}$ & \\
\hline Actin (ACTCl) & $\begin{array}{l}\text { HCM, increased likelihood of advanced left ventricular } \\
\text { dysfunction and heart failure [53], ASD [59] }\end{array}$ & Good prognosis [60] \\
\hline \multicolumn{3}{|l|}{ Non-sarcomeric genes } \\
\hline Titin (TTN) & Increases risk for cardiovascular death [61] & \\
\hline$\alpha$-actinin (ACTN1, ACTN2) & $\begin{array}{l}\text { HCM, syncope, heart failure and premature sudden } \\
\text { death [62] asymmetrical hypertrophy, early onset SVT } \\
\text { and AV bock [63] }\end{array}$ & $\begin{array}{l}\text { Mild cardiac hypertrophy but poor outcome in } \\
\text { affected individuals [ } 62]\end{array}$ \\
\hline$\alpha$-myosin heavy chain (MYH6) & $\begin{array}{l}\text { Late onset HCM [64], ASD [65], dilated } \\
\text { cardiomyopathy [66], susceptibility to sick sinus } \\
\text { syndrome [67] }\end{array}$ & \\
\hline Glycine-rich protein 3 (CSRP3) & $\begin{array}{l}\text { Pronounced HCM, onset of symptoms in young } \\
\text { adulthood, SCD can be seen, and dilated } \\
\text { cardiomyopathy [ } 68]\end{array}$ & Good prognosis in heterozygous carriers [69] \\
\hline Telethonin (TCAP) & $\begin{array}{l}\text { TCAP-HCM phenotypically resembles other } \\
\text { myofilament-HCM and is more severe than patients } \\
\text { who still remain without a disease-causing mutation, } \\
\text { dilated cardiomyopathy, age of onset around } 38.8 \pm 9 \text {, } \\
\text { dyspnea, angina [70] AD, alleles can cause limb girdle } \\
\text { myodystrophy [71] }\end{array}$ & \\
\hline Vinculin (VCL) & Cytoskeletal & \\
\hline
\end{tabular}

\begin{tabular}{ll}
\hline PTPN11 & $\begin{array}{l}50 \% \text { cases of Noonan syndrome, facial features include } \\
\text { widely spaced eyes, light-colored eyes, low-set ears, } \\
\text { a short neck, and a small lower jaw [14,72-74] }\end{array}$ \\
BRAF, KRAS, HRAS, RAF1, SOS1, SPRED1 & Noonan/Costello/cardio-cutaneous syndrome \\
\hline PTPN11 & Leopard syndrome \\
\hline Metabolic disorders &
\end{tabular}

[75-80]

[81]
GAA Pompe disease
Alpha-glucosidase deficiency (GSD). Levels of alpha-glucosidase determine the type of GSD II an individual may have $[82,83]$

Lysosomal storage disorder

Deficient alfa-galactosidase A enzyme X-linked disorder [84-86]
Anderson-Fabry disease, acroparesthesia, kidney dysfunction, skin manifestations (angiokeratoma, anhidrosis) and neuropathy

Lysosome-associated membrane protein $2[87,88]$ disorder associated with HCM, skeletal muscle weakness, and intellectual disability

ELAC2 gene (mitochondrial tRNA) HCM, psychomotor retardation/delay, muscular hypotonia, Poor outcome intrauterine growth retardation, microcephaly, dysphagia, hearing impairment [47]

\section{Systemic disorders}

TTR

Transthyretin amyloidosis [89-92]

Extracellular deposition of transthyretin

\section{Neuromuscular disorders}

\section{FRDA1}

Friedreich ataxia

ASD, atrial septal defect; AV, atrio-ventricular; GSD, glycogen storage disease; HCM, hypertrophic cardiomyopathy; SCD, sudden cardiac death; SVT, supraventricular tachycardia. 


\section{Counselling}

HCM is an inherited disease most frequently transmitted as autosomal dominant trait, followed by autosomal recessive, Xlinked transmission have been described and this has important reproductive implications [47]. This is particularly important in Saudi Arabia due to high rates of consanguinity. Counseling helps patients to be aware about the consequence of a genetic positive test for the proband and relative, the possibility to transmit the disease, eventual reproductive alternatives and ways to avoid transmission. In this context all cultural, social, ethical, legal aspects should be considered (Figure 8).

\section{Therapy}

Treatment in asymptomatic patients i.e., without LVOTO mainly focuses on the management of arrhythmias, reducing LV filling pressures, and the treatment of chest pain. Various therapies have been suggested for the treatment of symptomatic HCM. In patients with symptomatic LVOTO pharmacological agents such as non-vasodilating beta blockers are considered first line followed by non- dihydropyridine calcium channel blockers (verapamil) and lastly disopyramide or septal reduction is recommended for symptomatic relief. Just as important is to avoid the medications that may promote LVOTO such as dihydropyridine class calcium chan-

Table 3. Presentation of different disease etiology with preference age groups.

\begin{tabular}{|c|c|c|c|c|}
\hline & $\begin{array}{l}\text { Infants ( } 0-12 \text { months) } \\
\text { and toddlers }\end{array}$ & Early childhood & $\begin{array}{l}\text { School age and } \\
\text { adolescence }\end{array}$ & Adulthood \\
\hline Systemic features & $\begin{array}{l}\text { Metabolic acidosis, failure to } \\
\text { thrive, and dysmorphic features }\end{array}$ & $\begin{array}{l}\text { Abnormal or delayed cognitive } \\
\text { development, hearing/visual } \\
\text { deficits }\end{array}$ & $\begin{array}{l}\text { Skeletal muscle weakness } \\
\text { or movement disorder }\end{array}$ & $\begin{array}{l}\text { Kidney failure, peripheral neuritis, } \\
\text { movement disorder }\end{array}$ \\
\hline Differential diagnosis & $\begin{array}{l}\text { RASopathies, glycogen storage } \\
\text { disease, other metabolic or } \\
\text { mitochondrial diseases, infant } \\
\text { of a diabetic woman }\end{array}$ & $\begin{array}{l}\text { RASopathies, mitochondrial } \\
\text { diseases }\end{array}$ & $\begin{array}{l}\text { Mitochondrial disease, } \\
\text { Friedrich ataxia, or Danon } \\
\text { disease }\end{array}$ & $\begin{array}{l}\text { Glycogen storage diseases, } \\
\text { amyloidosis, or Anderson-Fabry } \\
\text { disease }\end{array}$ \\
\hline Diagnostic approach & $\begin{array}{l}\text { Genetics assessment } \\
\text { (geneticist assessment), } \\
\text { newborn metabolic screening, } \\
\text { and specific metabolic assays }\end{array}$ & $\begin{array}{l}\text { Biochemical screening, and } \\
\text { genetic testing }\end{array}$ & $\begin{array}{l}\text { Genetic testing, } \\
\text { neuromuscular } \\
\text { assessment, and } \\
\text { biochemical screening }\end{array}$ & $\begin{array}{l}\text { Biochemical screening, } \\
\text { neuromuscular assessment, and } \\
\text { genetic testing }\end{array}$ \\
\hline
\end{tabular}

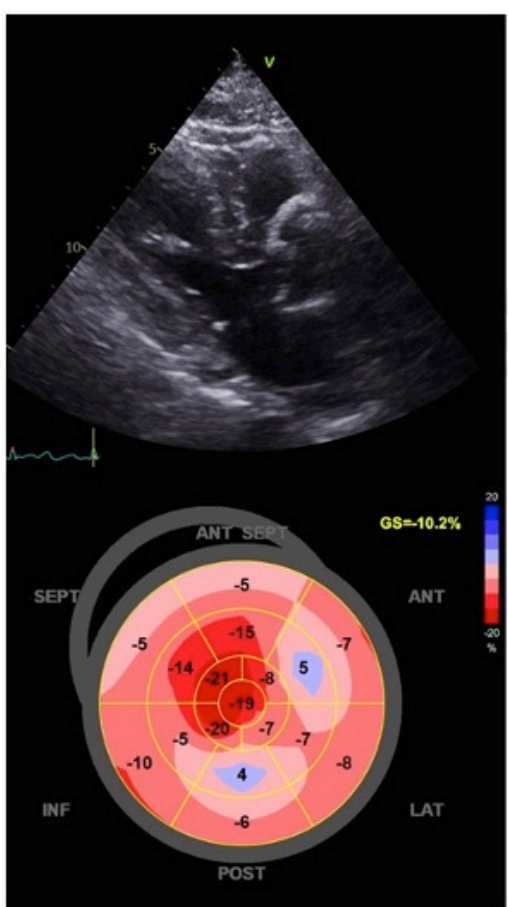

End stage renal disease

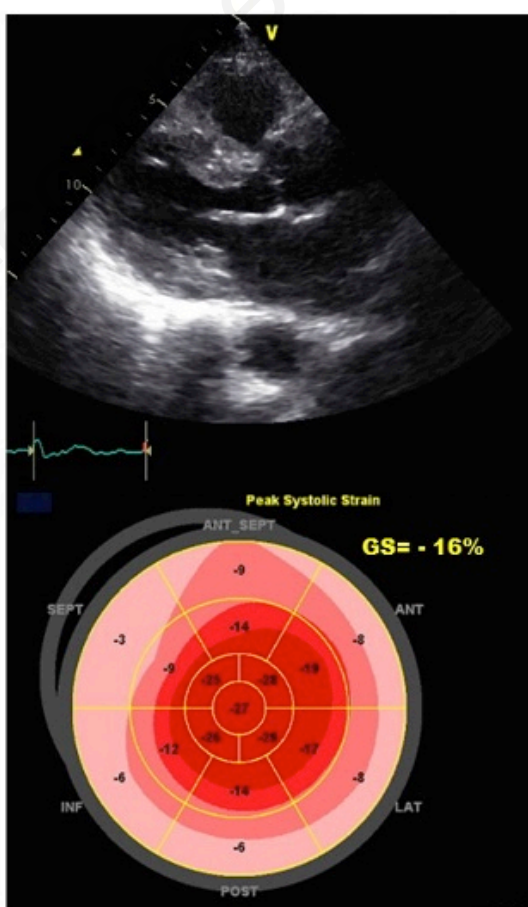

Amyloidosis

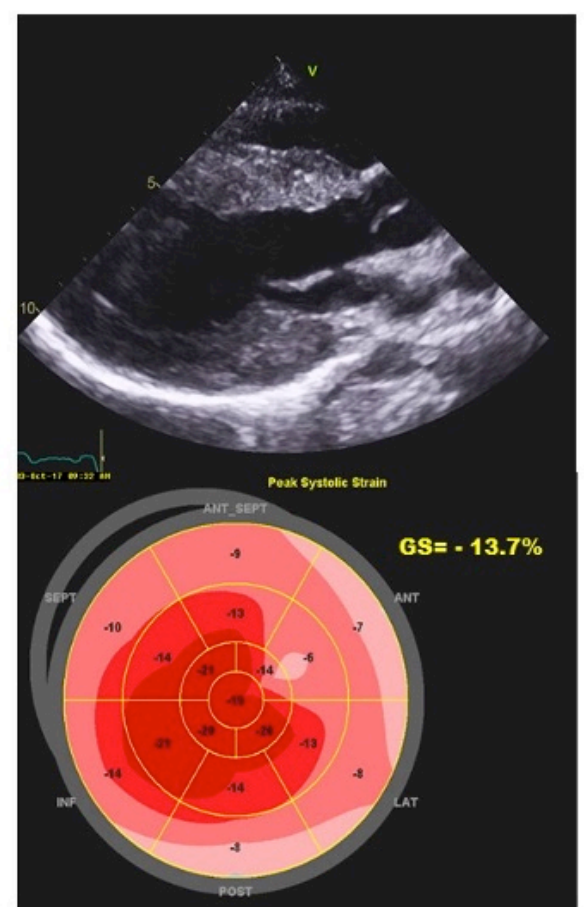

$\mathrm{HCM}$

Figure 6. Echocardiographic phenocopies. Phenotype in an 88-year-old patient with amyloidosis [interventricular septum (IVS) $18 \mathrm{~mm}$, posterior wall thickness (PWT) $16 \mathrm{~mm}$ ], a 35-year-old patient with end-stage renal disease (IVS $16 \mathrm{~mm}$, PWT $12 \mathrm{~mm}$ ), and a 24 -yearold patient with hypertrophic cardiomyopathy (IVS $18 \mathrm{~mm}$, PWT $17 \mathrm{~mm}$ ). 


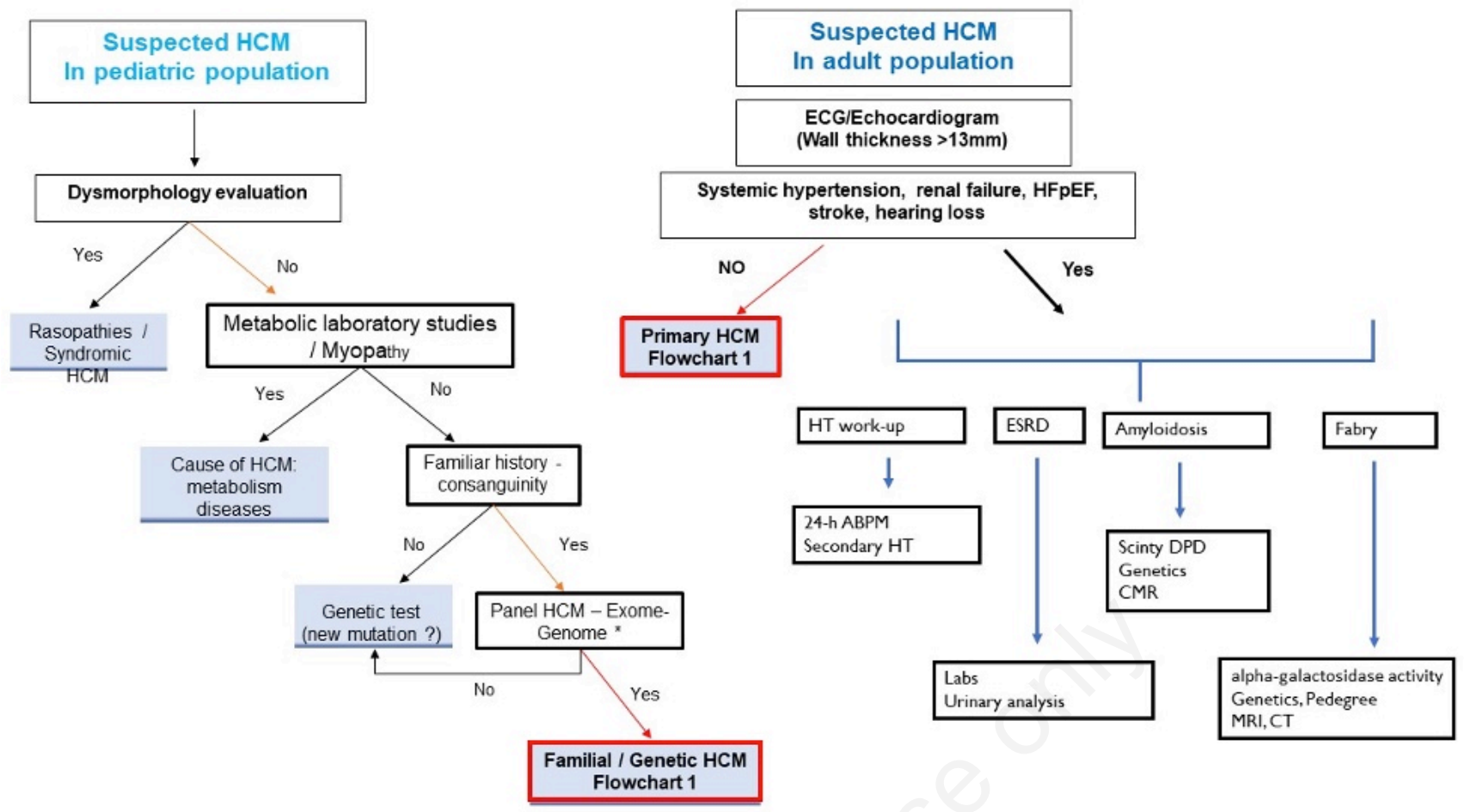

Figure 7. Flow chart for the management of suspected HCM. 24-h ABPM, 24-hour ambulatory blood pressure monitoring; CMR, cardiac magnetic resonance; CT, computed tomography; DPD, diphosphonates; ECG, electrocardiogram; ESRD, end-stage renal disease; HCM, hypertrophic cardiomyopathy; HFpEF, heart failure with preserved ejection fraction; HT, hypertension; MRI, magnetic resonance imaging.
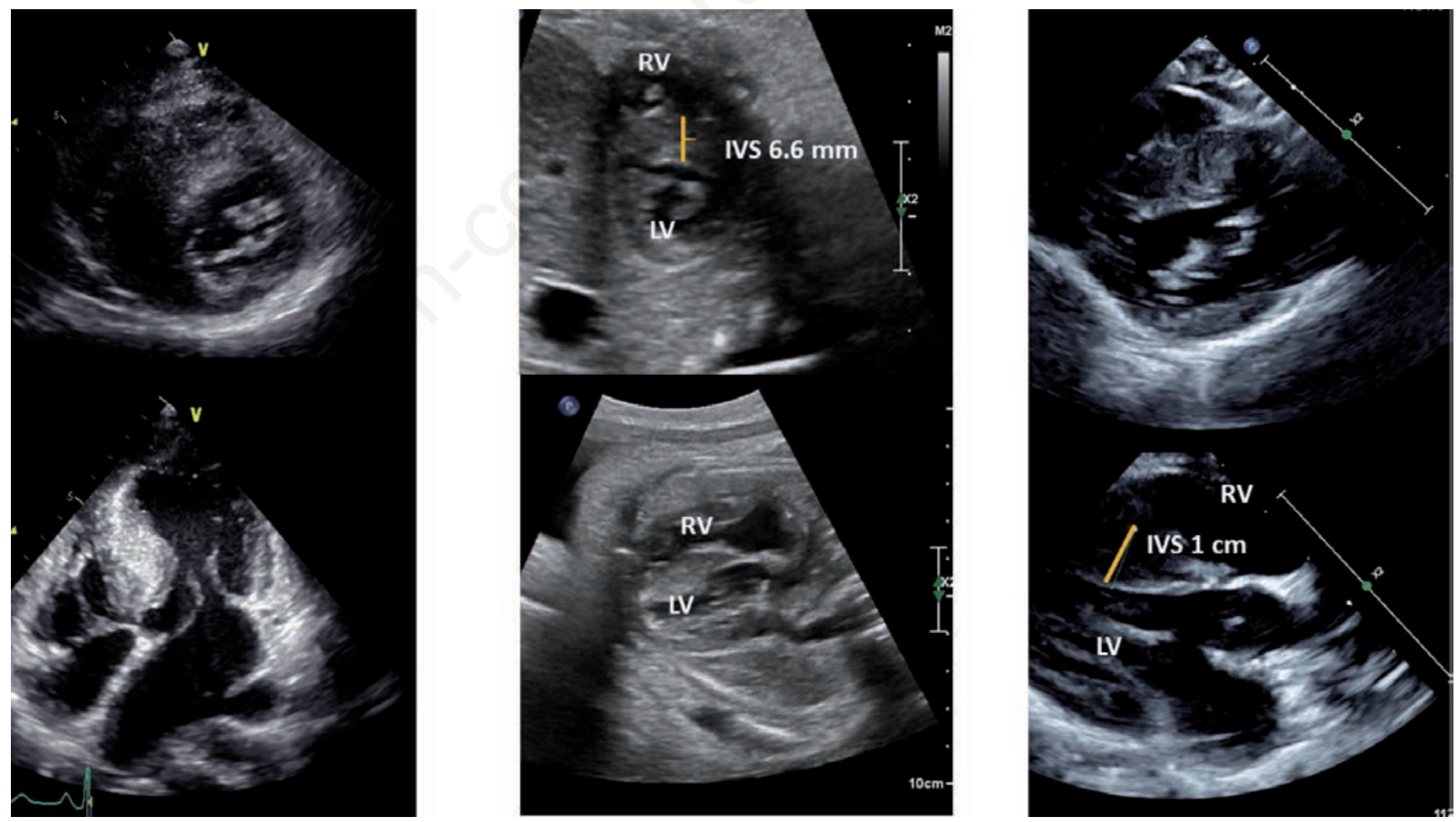

Figure 8. Mother and child with hypertrophic cardiomyopathy. A) Mother with S/P myomectomy in left ventricular outflow tract obstruction; first pregnancy ended with spontaneous abortion; genetic testing result of the fetus was Turner syndrome; second pregnancy: prenatal diagnosis of hypertrophic cardiomyopathy of the fetus. B) Fetus: moderate to severe hypertrophic myocardium mainly in the interventricular septum (IVS); echo at 34 weeks. C) Baby boy with hypertrophic cardiomyopathy at 5 months; gene expression of TPTN11 variant (Leopard); counseling could have helped planning the second pregnancy. LV, left ventricle; RV, right ventricle. 
nel blockers, angiotensin-converting enzyme inhibitors, angiotensin receptor blockers and high-dose diuretics.

Mavacamten is a first-in-class cardiac myosin inhibitor indicated in symptomatic obstructive hypertrophic cardiomyopathy with LVOT gradient ${ }^{3} 50 \mathrm{mmHg}$. Mavacamten is an allosteric modulator of cardiac myosin and acts reducing cardiac muscle contractility by inhibiting excessive myosin-actin cross bridge formation. The EXPLORER-HCM phase 3 trial, showed a reduction in LVOT gradient after exercise $(-36 \mathrm{mmHg})$, greater increase in $\mathrm{pVO} 2$ $(+1.4 \mathrm{ml} / \mathrm{Kg} / \mathrm{min})$, improved symptoms score, NYHA functional class, and the overall quality of life [99].

Patients with LVOT, who remain unresponsive to medical therapy can opt for septal reduction therapy in the form of surgical ventricular septal myectomy (Morrow procedure) or alcohol septal ablation, particularly among patients with NYHA functional class III or class IV. Transaortic extended septal myectomy is appropriate covering a broad range of patients with symptomatic, obstructive HCM [100,101].

The most effective strategy for lengthening life and preventing fatal, life threatening tachyarrhythmias is an implantable cardioverter-defibrillator (ICD), especially in high risk population [102]. This therapy proved to be equally as beneficial in children and adolescent with extreme left ventricular hypertrophy being the most common risk factor associated with future ICD interventions [103]. Adult and pediatric that have progressive left ventricular diastolic or systolic dysfunction that is refractory to pharmacological therapy may be candidates for cardiac transplantation or mechanical circulatory support [104]. All patients are also advised to stop excessive alcohol consumption, avoid dehydration, and are motivated to lose weight (Table 4) [7,99,105-125].

\section{Prognosis}

The majority of individuals with HCM are able to enjoy an active lifestyle and tend to live the average lifespan. This is particularly true for patients with HCM without significant LVOTO, however special considerations must be discussed thoroughly with patients regarding pregnancy, and physical exercise [7]. The most common HCM related death is due to sudden cardiac death (SCD), but with the evolution of contemporary medicine and treatment modalities, the overall mortality can effectively be reduced to $<1 \%$ per year [126]. In Table 5 subtypes of HCM are reported [127-145].

\section{Sudden death}

Sudden cardiac death is an unpredictable and devastating complication of HCM [146]. The pathophysiology is complex and not completely understood but genetic and molecular substrate, myofibrillar disarray, ventricular hypertrophy, microvascular

Table 4. Treatment options for patients with hypertrophic cardiomyopathy.

\begin{tabular}{|c|c|c|}
\hline Pharmacological drug & Uses & Adverse events \\
\hline Beta-blockers (non-vasodilating) & $\begin{array}{l}\text { Abolish and reduce resting provocable LVOTO; } \\
\text { Provide symptomatic relief; } \\
\text { Suppress arrhythmia [105-107] }\end{array}$ & Hypotension [7] \\
\hline Disopyramide (Class IA anti-arrhythmic) & $\begin{array}{l}\text { Abolish basal LV outflow pressure gradients; } \\
\text { Improves exercise tolerance }[108,109]\end{array}$ & $\begin{array}{l}\text { Dry eyes and mouth, urinary hesitancy or retention, and } \\
\text { constipation; } \\
\text { Prolonged QT [109] }\end{array}$ \\
\hline $\begin{array}{l}\text { Verapamil or diltiazem } \\
\text { (non-dihydropyridine) }\end{array}$ & $\begin{array}{l}\text { Increase exercise capacity; } \\
\text { Improve symptoms; } \\
\text { Normalize or improve LV diastolic filling [110-113] }\end{array}$ & $\begin{array}{l}\text { Pulmonary edema in patients with elevated pulmonary } \\
\text { artery systolic pressure [114] }\end{array}$ \\
\hline Low dose loop or thiazide diuretics & Improve dyspnea associated with LVOTO [7] & Hypovolemia worsening LVOTO [7] \\
\hline Mavacamten & $\begin{array}{l}\text { Improves exercise capacity and LVOTO; } \\
\text { Improves overall quality of life[99] }\end{array}$ & $\begin{array}{l}\text { Atrial fibrillation and decreased LV ejection fraction at } \\
\text { high concentrations [99] }\end{array}$ \\
\hline Invasive therapy & Uses & Adverse events \\
\hline Ventricular septal myectomy & $\begin{array}{l}\text { Reduces LVOT gradient; } \\
\text { Reduces systolic anterior motion MR; } \\
\text { Improves exercise intolerance }[115,116]\end{array}$ & $\begin{array}{l}\text { AV nodal block; Ventricular septal defect; } \\
\text { Aortic regurgitation [117] }\end{array}$ \\
\hline Septal alcohol ablation & $\begin{array}{l}\text { Reduces LVOT gradient; } \\
\text { Symptom improvement; } \\
\text { Increased exercise tolerance; } \\
\text { Larger residual LV outflow tract gradients [118] }\end{array}$ & AV block [119] \\
\hline Dual chamber pacing & $\begin{array}{l}\text { Reduces LVOT gradient; } \\
\text { Improves symptoms and quality of life }[120,121]\end{array}$ & $\begin{array}{l}\text { Spontaneous backup reversion, unexpected battery } \\
\text { depletion, total loss of telemetry without change in pacing } \\
\text { mode [122] }\end{array}$ \\
\hline Mitral clip & $\begin{array}{l}\text { Used to target SAM causing dynamic LVOTO; } \\
\text { Improves symptoms and quality of life }\end{array}$ & Recurrency of MR [123,124] \\
\hline Cardiac transplant & $\begin{array}{l}\text { Improves survival; } \\
\text { Only treatment option for drug refractory cases } \\
\text { without LVOTO [125] }\end{array}$ & $\begin{array}{l}\text { Rejection, cardiac allograft vasculopathy, } \\
\text { immunosuppressants effects }\end{array}$ \\
\hline
\end{tabular}

AV, atrio-ventricular; LV, left ventricular; LVOT, left ventricular outflow tract; LVOTO, left ventricular outflow tract obstruction; MR, mitral regurgitation; SAM, systolic anterior motion. 
ischemia and fibrosis predispose patients with HCM to re-entrant ventricular arrhythmias $[147,148]$. While it seems that there is no difference in SCD based on gender, age is an important factor. Patients younger than 35 years of age are particularly affected although $20 \%$ of SCD occurs in patients older than 65 years $[149,150]$. The European Society of Cardiology developed a riskSCD calculator where are included age, maximum LV wall thickness, left atrium, max LVOT gradient, family history of SCD, non-sustained VT, unexplained syncope (AHA HCM SCD calculator) [7].

To avoid this tragic event and in other patients is important to have the correct diagnosis. For this reason a complete autopsy must be performed according to well defined protocols; in case of death a molecular "autopsy" can diagnose the cause of death in $35 \%$ of patients [151]. In Saudi Arabia it is rarely performed but tissue samples from patients who underwent myomectomy and heart transplantation should be collected and preserved also for future pathologically revised using different techniques.

\section{Long term outcome}

The clinical course of HCM is less favorable in patients with the obstructive form of the disease and in the young compared to adult patients. Moreover, a small subgroup may progress to LV systolic dysfunction (ejection fraction less than 50\%), wall thinning, apical aneurysm, chamber enlargement, and progressive symptoms of heart failure. These patients are also at high risk of sudden death $[19,132,133,142,144]$. Surgical relief of LVOT obstruction, ICD implantation and medical therapy changed the natural history of the disease, nevertheless heart failure and $\mathrm{AF}$, especially in patients diagnosed at younger age and with sarcomere mutations, are still determinant factors of morbidity and mortality [117-120,125]. Heart failure is the clinical picture of the advanced stage of the disease, congestive heart failure therapy is recommended and later on heart transplantation can be the only definitive option to extend HCM patient life [152,153] (Table 6).

Table 5. Different phenotypes of hypertrophic cardiomyopathy and correlated prognosis.

\begin{tabular}{|c|c|c|c|c|c|}
\hline Subtype & $\begin{array}{l}\text { Percentage } \\
\text { of subtype }\end{array}$ & Prognosis & $\begin{array}{l}\text { Age of } \\
\text { development }\end{array}$ & Genetics & Complications \\
\hline $\begin{array}{l}\text { Isolated basal septal } \\
\text { hypertrophy [128-130] }\end{array}$ & $46 \%$ & $\begin{array}{l}15 \text {-year survival } \\
\text { similar to the general } \\
\text { population }\end{array}$ & Elderly & $\begin{array}{l}\text { Less than } 10 \% \text { of those } \\
\text { having positive findings } \\
\text { with the same genetic } \\
\text { test }\end{array}$ & $\begin{array}{l}\text { Angina and dizziness. } \\
\text { Hypertension and coronary } \\
\text { artery disease. } \\
\text { Systolic anterior motion }\end{array}$ \\
\hline $\begin{array}{l}\text { Reverse septal } \\
\text { curvature }[128,131]\end{array}$ & $40 \%$ & $\begin{array}{l}\text { Unfavorable prognosis } \\
\text { with increased septal } \\
\text { thickness at end } \\
\text { diastole/left } \\
\text { ventricular } \\
\text { end-diastolic } \\
\text { diameter ratio }\end{array}$ & Young population & $\begin{array}{l}\text { Genetic test for } \\
\text { myofilament HCM } \\
\text { (in 80\%), MYH7 }\end{array}$ & $\begin{array}{l}\text { Often associated with a family } \\
\text { history of SCD, hypertension, } \\
\text { and increased LVOT } \\
\text { pressure, syncope }\end{array}$ \\
\hline Apical HCM [132-134] & $\begin{array}{l}25 \% \text { in Japan to } 2 \% \\
\text { in western countries }\end{array}$ & Good & Middle aged men & $\begin{array}{l}\text { Most common mutations: } \\
\text { MYBPC3 and MYH7 }\end{array}$ & $\begin{array}{l}\text { Rarely associated with SCD, } \\
\text { associated with hypertension }\end{array}$ \\
\hline $\begin{array}{l}\text { Mid-cavity hypertrophy } \\
\text { (midventricular). } \\
\text { Could be complicated by } \\
\text { apical aneurysm } \\
\text { [135-138] }\end{array}$ & $2-5 \%$ & $\begin{array}{l}\text { Midventricular } \\
\text { obstruction is strongly } \\
\text { associated with } \\
\text { adverse effects }\end{array}$ & Middle aged men & $\begin{array}{l}44 \% \text { of patients with } \\
\text { midventricular } \\
\text { obstruction was } \\
\text { associated with some } \\
\text { form of cardiomyopathy } \\
\text { associated genetic } \\
\text { variant. } \\
21 \% \text { had a mutation in } \\
\text { sarcomere protein } \\
\text { (5.9\% MYH7, } 12 \% \text { MYBC3) }\end{array}$ & $\begin{array}{l}\text { Higher incidence of clinical } \\
\text { events. Risk of SCD of } 5 \% \text { per } \\
\text { year, ventricular arrhythmia, } \\
\text { myocardial necrosis, } \\
\text { systemic embolism, } \\
\text { obstruction and increased } \\
\text { gradient at midventricular } \\
\text { level }\end{array}$ \\
\hline $\begin{array}{l}\text { Symmetrical HCM } \\
{[138,139]}\end{array}$ & $42 \%$ & Variable & Middle aged & & LVOTO is common \\
\hline $\begin{array}{l}\text { Asymmetric (septal) } \\
\text { HCM [140-142] }\end{array}$ & $60-70 \%$ & Good & Middle aged men & & $\begin{array}{l}\text { Resting systolic pressure } \\
\text { gradient of the LVOT caused } \\
\text { by SAM of the mitral valve } \\
\text { leaflets, mitral regurgitation }\end{array}$ \\
\hline Mass-like HCM [138,143] & Rare & & & & $\begin{array}{l}\text { DD with neoplastic masses } \\
\text { Diagnosis by MRI } \\
\text { LVOTO seen if thickening is at } \\
\text { basal region }\end{array}$ \\
\hline $\begin{array}{l}\text { Non-contiguous HCM } \\
{[144,145]}\end{array}$ & $\begin{array}{l}\text { Found in } 42(13 \%) \\
\text { of } 333 \text { patients }\end{array}$ & & $35-73$ & & Dyspnea, sleep apnea \\
\hline
\end{tabular}

DD, differential diagnosis; HCM, hypertrophic cardiomyopathy; LVOT, left ventricular outflow tract; LVOTO, left ventricular outflow tract obstruction; MRI, magnetic resonance imaging; SAM, systolic anterior motion; SCD, sudden cardiac death. 
Table 6. Therapy in associated condition that complicate hypertrophic cardiomyopathy.

\begin{tabular}{|c|c|c|}
\hline \multicolumn{3}{|c|}{ Clinical conditions associated with HCM } \\
\hline Dyspnea and angina in non-LVOTO & $\begin{array}{l}\text { Beta-blockers (propranolol, atenolol, nadolol, } \\
\text { metoprolol, bisoprolol) } \\
\text { Oral diuretics } \\
\text { ACEi or ARB } \\
\text { MRA }\end{array}$ & $\begin{array}{l}\text { Bisoprolol in end-stage HF and usually not useful in LVOT } \\
\text { Despite the use of beta-blockers or calcium channel blockers } \\
(\mathrm{EF}<50 \%) \\
(\mathrm{EF}<50 \%)\end{array}$ \\
\hline AFVentricular rate control & $\begin{array}{l}\text { Bisoprolol or carvedilol } \\
\text { Verapamil or diltiazem } \\
\text { Digoxin }\end{array}$ & $\begin{array}{l}\text { LV systolic dysfunction } \\
\text { Only with preserved LVEF } \\
\text { Only if LVEF }<50 \% \text { and no LVOTO }\end{array}$ \\
\hline Prevention of cardioembolic events & NOAC & Independently of CHA2DS2-VASc score \\
\hline Prevention of AF recurrences & $\begin{array}{l}\text { Amiodarone, sotalol (Class III antiarrhythmic drug) } \\
\text { Disopyramide }\end{array}$ & In LVOTO associated with beta-blockers and verapamil \\
\hline $\mathrm{HF}$ & $\begin{array}{l}\text { ACEi or ARB } \\
\text { Sacubitril/valsartan }\end{array}$ & $\mathrm{HF}$ with reduced $\mathrm{EF}$ \\
\hline \multicolumn{3}{|l|}{ Ventricular arrhythmias } \\
\hline Reduction of NSVT & $\begin{array}{l}\text { Amiodarone } \\
\text { Sotalol }\end{array}$ & \\
\hline $\begin{array}{l}\text { Reduction of symptomatic tachycardia } \\
\text { or recurrent shock (ICD) }\end{array}$ & $\begin{array}{l}\text { Amiodarone } \\
\text { Beta-blockers }\end{array}$ & \\
\hline
\end{tabular}

ACEi, angiotensin-converting enzyme inhibitor; ARBs, angiotensin receptor blocker; CHA2DS2-VASc, Congestive heart failure, Hypertension, Age $\geq 75$ years, Diabetes mellitus, Stroke, Vascular disease, Age 65-74 years, Sex category (female); EF, ejection fraction; HF, heart failure; ICD, implantable cardioverter-defibrillator; LV, left ventricular; LVEF, left ventricular ejection fraction; LVOT, left ventricular outflow tract; LVOTO, left ventricular outflow tract obstruction; MRA, mineralocorticoid receptor antagonist; NOAC, new oral anticoagulant; NSVT, non-sustained ventricular tachycardia.

\section{Telemedicine and teleconsulting}

The experience of the SHaRe registry has shed new light on the importance of telemedicine and teleconsulting for the diagnosis and management of HCM, allowing a better understanding of the factors contributing to the heterogeneous outcomes in this complex disease [154,155]. The European Reference Network for Rare and Low prevalence Complex Diseases of the Heart (ERN-GUARD Heart) has been conceived as a virtual network involving healthcare providers across Europe aiming to give patients affected by rare and complex heart disease access to highly-specialized centers and best standards of care [96]. In addition, the spread of COVID19 pandemic and the restrictions imposed by local Governments significantly limited patients and healthcare professionals' international exchanges. Consequently, telehealth networks have assumed pivotal importance during COVID-19 pandemics, particularly for rare and complex diseases requiring highly specialized multidisciplinary teams.

To our knowledge, we proposed the first teleconsulting network between Saudi Arabia and Italy for the management and diagnosis of HCM and complex heart diseases. The HCMExtended Family Unit consists in a virtual network involving different specialists including cardiologists, cardiac surgeons, geneticists, neurologists, pediatric cardiologists and metabolisms experts aiming to discuss the best management for complex and rare disease of the heart, both in adults and pediatric patients. In addition, the cooperation between Saudi Arabia and Italy aims to provide new scientific perspectives in the understanding of rare cardiovascular diseases, with the creation of shared datasets and digital platforms and multicenter research protocols.

\section{Conclusions}

$\mathrm{HCM}$ is a relatively rare disease, most of the patients can have a good quality of life but accurate diagnosis starting with the family screening and the identification of phenocopies. The HCMFamily Unit is a "way of working" where health care professionals such as cardiologists, internists, cardiovascular surgeons, geneticists, pediatric cardiologists, nurses, psychologists are involved. Moreover, international cooperation is mandatory given the relatively uncommon/rare disease in order to share knowledge, create a research platform that will undoubtedly improve the quality of health care.

\section{References}

1. Teekakirikul P, Padera RF, Seidman JG, Seidman CE. Hypertrophic cardiomyopathy: translating cellular cross talk into therapeutics. J Cell Biol 2012;199:417-21.

2. Ommen SR, Mital S, Burke MA, et al. 2020 AHA/ACC Guideline for the diagnosis and treatment of patients with hypertrophic cardiomyopathy: Executive Summary: A report of the American College of Cardiology/American Heart Association Joint Committee on clinical practice guidelines. Circulation 2020;142:e533-57.

3. Maron BJ, Gardin JM, Flack JM, et al. Prevalence of hypertrophic cardiomyopathy in a general population of young adults: Echocardiographic analysis of 4111 subjects in the CARDIA study. Circulation 1995;92:785-9. 
4. Semsarian C, Ingles J, Maron MS, Maron BJ. New perspectives on the prevalence of hypertrophic cardiomyopathy. J Am Coll Cardiol 2015;65:1249-54.

5. Maron BJ, Rowin EJ, Maron MS. Global burden of hypertrophic cardiomyopathy. JACC Heart Fail 2018;6:376-8.

6. Ahmed W, Akhtar N, Bech-Hanssen O, et al. Hypertrophic cardiomyopathy in the Saudi Arabian population: Clinical and echocardiographic characteristics and outcome analysis. J Saudi Heart Assoc 2014;26:7-13.

7. Authors/Task Force members, Elliott PM, Anastasakis A, et al. 2014 ESC Guidelines on diagnosis and management of hypertrophic cardiomyopathy: the Task Force for the Diagnosis and Management of Hypertrophic Cardiomyopathy of the European Society of Cardiology (ESC). Eur Heart J 2014;35:2733-79.

8. Ingles J, Burns C, Bagnall RD, et al. Nonfamilial hypertrophic cardiomyopathy. Circ Cardiovasc Genet 2017;10:e001620.

9. Verdecchia P, Carini G, Circo A, et al. Left ventricular mass and cardiovascular morbidity in essential hypertension: the MAVI study. J Am Coll Cardiol 2001;38:1829-35.

10. Koren MJ, Devereux RB, Casale PN, et al. Relation of left ventricular mass and geometry to morbidity and mortality in uncomplicated essential hypertension. Ann Intern Med 1991;114:345-52.

11. Casale PN, Devereux RB, Milner M, et al. Value of echocardiographic measurement of left ventricular mass in predicting cardiovascular morbid events in hypertensive men. Ann Intern Med 1986;105:173-8.

12. Pelliccia F, Alfieri O, Calabrò $P$, et al. Multidisciplinary evaluation and management of obstructive hypertrophic cardiomyopathy in 2020: Towards the HCM Heart Team. Int J Cardiol 2020;304:86-92.

13. Marston NA, Han L, Olivotto I, et al. Clinical characteristics and outcomes in childhood-onset hypertrophic cardiomyopathy. Eur Heart J 2021;42:1988-96.

14. Monda E, Rubino M, Lioncino M, et al. Hypertrophic cardiomyopathy in children: pathophysiology, diagnosis, and treatment of non-sarcomeric causes. Front Pediatr 2021;9:632293.

15. Barriales-Villa R, Gimeno-Blanes JR, Zorio-Grima E, et al. Plan of action for inherited cardiovascular diseases: Synthesis of recommendations and action algorithms. Rev Esp Cardiol (Engl Ed) 2016;69:300-9.

16. Biagini E, Spirito P, Rocchi G, et al. Prognostic implications of the Doppler restrictive filling pattern in hypertrophic cardiomyopathy. Am J Cardiol 2009;104:1727-31.

17. Sen-Chowdhry S, Jacoby D, Moon JC, McKenna WJ. Update on hypertrophic cardiomyopathy and a guide to the guidelines. Nat Rev Cardiol 2016;13:651-75.

18. Maron MS, Olivotto I, Zenovich AG, et al. Hypertrophic cardiomyopathy is predominantly a disease of left ventricular outflow tract obstruction. Circulation 2006;114:2232-9.

19. Yang K, Song Y-Y, Chen X-Y, et al. Apical hypertrophic cardiomyopathy with left ventricular apical aneurysm: prevalence, cardiac magnetic resonance characteristics, and prognosis. Eur Heart J Cardiovasc Imaging 2020;21: 1341-50.

20. Rowin EJ, Maron BJ, Haas TS, et al. Hypertrophic cardiomyopathy with left ventricular apical aneurysm: Implications for risk stratification and management. J Am Coll Cardiol 2017;69:761-73.

21. Basso C, Thiene G, Mackey-Bojack S, et al. Myocardial bridging, a frequent component of the hypertrophic cardiomy- opathy phenotype, lacks systematic association with sudden cardiac death. Eur Heart J 2009;30:1627-34.

22. Abuarqoub A, Naranjo M, Shamoon F. Myocardial bridging with left ventricular hypertrophy presenting as Wellens pattern. Ann Transl Med 2017;5:401.

23. Díez-López C, Salazar-Mendiguchía J. Clinical presentations of hypertrophic cardiomyopathy and implications for therapy. Glob Cardiol Sci Pract 2018;2018:19.

24. Olivotto I, Girolami F, Sciagr R, et al. Microvascular function is selectively impaired in patients with hypertrophic cardiomyopathy and sarcomere myofilament gene mutations. J Am Coll Cardiol 2011;58:839-48.

25. Schulze-Bahr E, Klaassen S, Abdul-Khaliq H, Schunkert H. [Molecular diagnosis for cardiovascular diseases].[Article in German]. Dtsch Med Wochenschr 2015;140:1538.

26. McLeod CJ, Ackerman MJ, Nishimura RA, et al. Outcome of patients with hypertrophic cardiomyopathy and a normal electrocardiogram. J Am Coll Cardiol 2009;54:229-33.

27. Finocchiaro G, Sheikh N, Biagini E, et al. The electrocardiogram in the diagnosis and management of patients with hypertrophic cardiomyopathy. Hear Rhythm 2020;17:142-51.

28. Maron BJ, Ackerman MJ, Nishimura RA, et al. Task Force 4: HCM and other cardiomyopathies, mitral valve prolapse, myocarditis, and Marfan syndrome. J Am Coll Cardiol 2005;45:1340-5.

29. Patten M, Pecha S, Aydin A. Atrial fibrillation in hypertrophic cardiomyopathy: Diagnosis and considerations for management. J Atr Fibrillation 2018;10:1556.

30. Maron MS, Rowin EJ, Maron BJ. How to image hypertrophic cardiomyopathy. Circ Cardiovasc Imaging 2017;10:e005372.

31. Klues HG, Schiffers A, Maron BJ. Phenotypic spectrum and patterns of left ventricular hypertrophy in hypertrophic cardiomyopathy: morphologic observations and significance as assessed by two-dimensional echocardiography in 600 patients. J Am Coll Cardiol 1995;26:1699-708.

32. Haland TF, Edvardsen T. The role of echocardiography in management of hypertrophic cardiomyopathy. J Echocardiogr 2020;18:77-85.

33. Schroeder S, Achenbach S, Bengel F, et al. Cardiac computed tomography: indications, applications, limitations, and training requirements: report of a Writing Group deployed by the Working Group Nuclear Cardiology and Cardiac CT of the European Society of Cardiology and the European Council of Nuc. Eur Heart J 2008;29:531-56.

34. Alegria JR, Herrmann J, Holmes DR, et al. Myocardial bridging. Eur Heart J 2005;26:1159-68.

35. Maron BJ, Doerer JJ, Haas TS, et al.Sudden deaths in young competitive athletes: analysis of 1866 deaths in the United States, 1980-2006. Circulation 2009;119:1085-92.

36. Lairez O. [Hypertrophic cardiomyopathies].[Article in French]. Rev Med Interne 2019;40:380-8.

37. Mogensen J, Kubo T, Duque M, et al. Idiopathic restrictive cardiomyopathy is part of the clinical expression of cardiac troponin I mutations. J Clin Invest 2003;111:209-16.

38. Olivotto I, Cecchi F, Poggesi C, Yacoub MH. Patterns of disease progression in hypertrophic cardiomyopathy: an individualized approach to clinical staging. Circ Heart Fail 2012;5:535-46.

39. Kubo T, Gimeno JR, Bahl A, et al. Prevalence, clinical significance, and genetic basis of hypertrophic cardiomyopathy with restrictive phenotype. J Am Coll Cardiol 2007; 49:2419-26

40. De Bortoli M, Vio R, Basso C, et al. Novel missense variant 
in MYL2 gene associated with hypertrophic cardiomyopathy showing high incidence of restrictive physiology. Circ Genomic Precis Med 2020;13:e002824.

41. Rapezzi C, Arbustini E, Caforio ALP, et al. Diagnostic workup in cardiomyopathies: bridging the gap between clinical phenotypes and final diagnosis. A position statement from the ESC Working Group on Myocardial and Pericardial Diseases. Eur Heart J 2013;34:1448-58.

42. Charron P, Arad M, Arbustini E, et al. Genetic counselling and testing in cardiomyopathies: a position statement of the European Society of Cardiology Working Group on Myocardial and Pericardial Diseases. Eur Heart J 2010;31:2715-26.

43. Teekakirikul P, Kelly MA, Rehm HL, et al. Inherited cardiomyopathies: molecular genetics and clinical genetic testing in the postgenomic era. J Mol Diagn 2013;15:158-70.

44. Teekakirikul P, Zhu W, Huang HC, Fung E. Hypertrophic cardiomyopathy: An overview of genetics and management. Biomolecules 2019;9:878.

45. Richard P, Charron P, Carrier L, et al. Hypertrophic cardiomyopathy: Distribution of disease genes, spectrum of mutations, and implications for a molecular diagnosis strategy. Circulation 2003;107:2227-32.

46. Walsh R, Thomson KL, Ware JS, et al. Reassessment of Mendelian gene pathogenicity using 7,855 cardiomyopathy cases and 60,706 reference samples. Genet Med 2017;19: 192-203.

47. Shinwari ZMA, Almesned A, Alakhfash A, et al. The phenotype and outcome of infantile cardiomyopathy caused by a homozygous ELAC2 mutation. Cardiology 2017;137:188-92.

48. Charron P, Dubourg O, Desnos M, et al. Clinical features and prognostic implications of familial hypertrophic cardiomyopathy related to the cardiac myosin-binding protein $\mathrm{C}$ gene. Circulation 1998;97:2230-6.

49. Fiorillo C, Astrea G, Savarese M, et al. MYH7-related myopathies: clinical, histopathological and imaging findings in a cohort of Italian patients. Orphanet J Rare Dis 2016;11:91.

50. Watkins H, Rosenzweig A, Hwang DS, et al. Characteristics and prognostic implications of myosin missense mutations in familial hypertrophic cardiomyopathy. $N$ Engl J Med 1992;326:1108-14.

51. Pasquale F, Syrris P, Kaski JP, et al. Long-term outcomes in hypertrophic cardiomyopathy caused by mutations in the cardiac troponin T gene. Circ Cardiovasc Genet 2012;5:10-7.

52. van den Wijngaard A, Volders P, Van Tintelen JP, et al. Recurrent and founder mutations in the Netherlands: cardiac Troponin I (TNNI3) gene mutations as a cause of severe forms of hypertrophic and restrictive cardiomyopathy. Neth Heart J 2011;19:344-51.

53. Coppini R, Ho CY, Ashley E, et al. Clinical phenotype and outcome of hypertrophic cardiomyopathy associated with thin-filament gene mutations. J Am Coll Cardiol 2014;64:2589-600.

54. Karibe A, Tobacman LS, Strand J, et al. Hypertrophic cardiomyopathy caused by a novel alpha-tropomyosin mutation (V95A) is associated with mild cardiac phenotype, abnormal calcium binding to troponin, abnormal myosin cycling, and poor prognosis. Circulation 2001;103:65-71.

55. Flavigny $\mathrm{J}$, Richard $\mathrm{P}$, Isnard $\mathrm{R}, \mathrm{C}$ et al. Identification of two novel mutations in the ventricular regulatory myosin light chain gene (MYL2) associated with familial and classical forms of hypertrophic cardiomyopathy. J Mol Med (Berl) 1998;76:208-14.
56. Andersen PS, Havndrup O, Bundgaard H, et al. Myosin light chain mutations in familial hypertrophic cardiomyopathy: phenotypic presentation and frequency in Danish and South African populations. J Med Genet 2001;38:E43.

57. Yadav S, Sitbon YH, Kazmierczak K, Szczesna-Cordary D. Hereditary heart disease: pathophysiology, clinical presentation, and animal models of HCM, RCM, and DCM associated with mutations in cardiac myosin light chains. Pflugers Arch 2019;471:683-99.

58. Gurr MI. Lipid metabolism in man. Proc Nutr Soc 1988;47:277-85.

59. Matsson H, Eason J, Bookwalter CS, et al. Alpha-cardiac actin mutations produce atrial septal defects. Hum Mol Genet 2008; 17:256-65.

60. Cicerchia M, Ochoa J, Cardenas-Reyes I, et al. Genotype/phenotype correlation and prognosis for undescribed ACTC1 missense variants. Eur Heart J 2020;41:ehaa946.2075.

61. Zhang $\mathrm{C}$, Zhang $\mathrm{H}, \mathrm{Wu} \mathrm{G}$, et al. Titin-truncating variants increase the risk of cardiovascular death in patients with hypertrophic cardiomyopathy. Can J Cardiol 2017;33:1292-7.

62. Chiu $\mathrm{C}$, Bagnall RD, Ingles $\mathrm{J}$, et al. Mutations in alphaactinin-2 cause hypertrophic cardiomyopathy: a genome-wide analysis. J Am Coll Cardiol 2010;55:1127-35.

63. Girolami F, Iascone M, Tomberli B, et al. Novel $\alpha$-actinin 2 variant associated with familial hypertrophic cardiomyopathy and juvenile atrial arrhythmias: a massively parallel sequencing study. Circ Cardiovasc Genet 2014;7:741-50.

64. Niimura H, Patton KK, McKenna WJ, et al. Sarcomere protein gene mutations in hypertrophic cardiomyopathy of the elderly. Circulation 2002;105:446-51.

65. Ching Y-H, Ghosh TK, Cross SJ, et al. Mutation in myosin heavy chain 6 causes atrial septal defect. Nat Genet 2005;37:423-8.

66. Carniel E, Taylor MRG, Sinagra G, et al. Alpha-myosin heavy chain: a sarcomeric gene associated with dilated and hypertrophic phenotypes of cardiomyopathy. Circulation 2005;112:54-9.

67. Ishikawa T, Jou CJ, Nogami A, et al. Novel mutation in the $\alpha$ myosin heavy chain gene is associated with sick sinus syndrome. Circ Arrhythm Electrophysiol 2015;8:400-8.

68. Geier C, Gehmlich K, Ehler E, et al. Beyond the sarcomere: CSRP3 mutations cause hypertrophic cardiomyopathy. Hum Mol Genet 2008; 17:2753-65.

69. Salazar-Mendiguchía J, Barriales-Villa R, Lopes LR, et al. The p.(Cys150Tyr) variant in CSRP3 is associated with lateonset hypertrophic cardiomyopathy in heterozygous individuals. Eur J Med Genet 2020;63:104079.

70. Bos JM, Poley RN, Ny M, et al. Genotype-phenotype relationships involving hypertrophic cardiomyopathy-associated mutations in titin, muscle LIM protein, and telethonin. Mol Genet Metab 2006;88:78-85.

71. Cirino AL, Ho C. Hypertrophic cardiomyopathy overview. In: Adam MP, Ardinger HH, Pagon RA, et al., editors. GeneReviews ${ }^{\circledR}$ [Internet]. Seattle: University of Washington, Seattle; 1993-2021. Available from: https://www.ncbi. nlm.nih.gov/books/NBK1768/

72. Jhang WK, Choi J-H, Lee BH, et al. Cardiac Manifestations and associations with gene mutations in patients diagnosed with RASopathies. Pediatr Cardiol 2016;37:1539-47.

73. Digilio MC, Conti E, Sarkozy A, et al. Grouping of multiplelentigines/LEOPARD and Noonan syndromes on the PTPN11 gene. Am J Hum Genet 2002;71:389-94.

74. Caiazza M, Rubino M, Monda E, et al. Combined PTPN11 
and MYBPC3 gene mutations in an adult patient with Noonan syndrome and hypertrophic cardiomyopathy. Genes (Basel) 2020;11:947.

75. Aoki Y, Niihori T, Kawame H, et al. Germline mutations in HRAS proto-oncogene cause Costello syndrome. Nat Genet 2005;37:1038-40.

76. Pandit B, Sarkozy A, Pennacchio LA, et al. Gain-of-function RAF1 mutations cause Noonan and LEOPARD syndromes with hypertrophic cardiomyopathy. Nat Genet 2007;39:1007-12.

77. Tartaglia M, Pennacchio LA, Zhao C, et al. Gain-of-function SOS1 mutations cause a distinctive form of Noonan syndrome. Nat Genet 2007;39:75-9.

78. Roberts AE, Araki T, Swanson KD, et al. Germline gain-offunction mutations in SOS1 cause Noonan syndrome. Nat Genet 2007;39:70-4.

79. Rodriguez-Viciana P, Tetsu O, Tidyman WE, et al. Germline mutations in genes within the MAPK pathway cause cardiofacio-cutaneous syndrome. Science 2006;311:1287-90.

80. Niihori T, Aoki Y, Narumi Y, et al. Germline KRAS and BRAF mutations in cardio-facio-cutaneous syndrome. Nat Genet 2006;38:294-6.

81. Legius E, Schrander-Stumpel C, Schollen E, et al. PTPN11 mutations in LEOPARD syndrome. J Med Genet 2002;39:571-4.

82. Martiniuk F, Mehler M, Pellicer A, et al. Isolation of a cDNA for human acid alpha-glucosidase and detection of genetic heterogeneity for mRNA in three alpha-glucosidase-deficient patients. Proc Natl Acad Sci USA 1986;83:9641-4.

83. Van der Ploeg AT, Hoefsloot LH, Hoogeveen-Westerveld M, et al. Glycogenosis type II: protein and DNA analysis in five South African families from various ethnic origins. Am J Hum Genet 1989;44:787-93.

84. Bernstein HS, Bishop DF, Astrin KH, et al. Fabry disease: six gene rearrangements and an exonic point mutation in the alpha-galactosidase gene. J Clin Invest 1989;83:1390-9.

85. Davies JP, Winchester BG, Malcolm S. Mutation analysis in patients with the typical form of Anderson-Fabry disease. Hum Mol Genet 1993;2:1051-3.

86. Eng CM, Desnick RJ. Molecular basis of Fabry disease: mutations and polymorphisms in the human alpha-galactosidase A gene. Hum Mutat 1994;3:103-11.

87. Arad M, Maron BJ, Gorham JM, et al. Glycogen storage diseases presenting as hypertrophic cardiomyopathy. N Engl J Med 2005;352:362-72.

88. Charron P, Villard E, Sébillon P, et al. Danon's disease as a cause of hypertrophic cardiomyopathy: a systematic survey. Heart 2004;90:842-6.

89. Benson MD. Inherited amyloidosis. J Med Genet 1991; 28:73-8.

90. Saraiva MJ. Transthyretin mutations in health and disease. Hum Mutat 1995;5:191-6.

91. Saraiva MJ. Transthyretin mutations in hyperthyroxinemia and amyloid diseases. Hum Mutat 2001;17:493-503.

92. Lachmann HJ, Booth DR, Booth SE, et al. Misdiagnosis of hereditary amyloidosis as AL (primary) amyloidosis. N Engl J Med 2002;346:1786-91.

93. Blair E, Price SJ, Baty CJ, et al. Mutations in cis can confound genotype-phenotype correlations in hypertrophic cardiomyopathy. J Med Genet 2001;38:385-8.

94. Maron BJ, Maron MS, Semsarian C. Double or compound sarcomere mutations in hypertrophic cardiomyopathy: a potential link to sudden death in the absence of conventional risk factors. Heart Rhythm 2012;9:57-63.
95. Girolami F, Ho CY, Semsarian C, et al. Clinical features and outcome of hypertrophic cardiomyopathy associated with triple sarcomere protein gene mutations. J Am Coll Cardiol 2010;55:1444-53.

96. European Reference Network for Rare and Low Prevalence Complex Diseases of the Heart [Internet]. Target Groups. 2021. Accessed: 10 October 2021. Available from: https:/guardheart.ern-net.eu/ern-guard-heart/target-groups/

97. Merlini G, Bellotti V. Molecular mechanisms of amyloidosis. N Engl J Med 2003;349:583-96.

98. Tanaka H. Efficacy of echocardiography for differential diagnosis of left ventricular hypertrophy: special focus on speckle-tracking longitudinal strain. J Echocardiogr 2021;19:71-9.

99. Olivotto I, Oreziak A, Barriales-Villa R, et al. Mavacamten for treatment of symptomatic obstructive hypertrophic cardiomyopathy (EXPLORER-HCM): a randomised, doubleblind, placebo-controlled, phase 3 trial. Lancet 2020; 396:759-69.

100. Nguyen A, Schaff H V. Surgical myectomy: Subaortic, midventricular, and apical. Cardiol Clin 2019;37:95-104.

101. Said SM, Schaff HV, Abel MD, Dearani JA. Transapical approach for apical myectomy and relief of midventricular obstruction in hypertrophic cardiomyopathy. J Card Surg 2012;27:443-8.

102. Maron BJ, Spirito P, Shen W-K, et al. Implantable cardioverter-defibrillators and prevention of sudden cardiac death in hypertrophic cardiomyopathy. JAMA 2007;298:405-12.

103. Maron BJ, Spirito P, Ackerman MJ, et al. Prevention of sudden cardiac death with implantable cardioverter-defibrillators in children and adolescents with hypertrophic cardiomyopathy. J Am Coll Cardiol 2013;61:1527-35.

104. Monda E, Lioncino M, Pacileo R, et al. Advanced heart failure in special population-Pediatric age. Heart Fail Clin 2021;17:673-83.

105. Adelman AG, Shah PM, Gramiak R, Wigle ED. Long-term propranolol therapy in muscular subaortic stenosis. Br Heart J 1970;32:804-11.

106. Stenson RE, Flamm MD, Harrison DC, Hancock EW. Hypertrophic subaortic stenosis. Clinical and hemodynamic effects of long-term propranolol therapy. Am J Cardiol 1973;31:763-73.

107. Flamm MD, Harrison DC, Hancock EW. Muscular subaortic stenosis. Prevention of outflow obstruction with propranolol. Circulation 1968;38:846-58.

108. Sherrid MV, Barac I, McKenna WJ, et al. Multicenter study of the efficacy and safety of disopyramide in obstructive hypertrophic cardiomyopathy. J Am Coll Cardiol 2005;45:1251-8.

109. Sherrid MV, Shetty A, Winson G, et al. Treatment of obstructive hypertrophic cardiomyopathy symptoms and gradient resistant to first-line therapy with $\beta$-blockade or verapamil. Circ Heart Fail 2013;6:694-702.

110. Rosing DR, Kent KM, Borer JS, et al. Verapamil therapy: a new approach to the pharmacologic treatment of hypertrophic cardiomyopathy. I. Hemodynamic effects. Circulation 1979;60:1201-7.

111. Bonow RO, Rosing DR, Epstein SE. The acute and chronic effects of verapamil on left ventricular function in patients with hypertrophic cardiomyopathy. Eur Heart J 1983;4:S57-65.

112. Spicer RL, Rocchini AP, Crowley DC, et al. Hemodynamic effects of verapamil in children and adolescents with hypertrophic cardiomyopathy. Circulation 1983;67:413-20.

113. Rosing DR, Idänpään-Heikkilä U, Maron BJ, Bonow RO, Epstein SE. Use of calcium-channel blocking drugs in hyper- 
trophic cardiomyopathy. Am J Cardiol 1985;55:185B-95.

114. Epstein SE, Rosing DR. Verapamil: its potential for causing serious complications in patients with hypertrophic cardiomyopathy. Circulation 1981;64:437-41.

115. Robbins RC, Stinson EB. Long-term results of left ventricular myotomy and myectomy for obstructive hypertrophic cardiomyopathy. J Thorac Cardiovasc Surg 1996;111:586-94.

116. Schönbeck MH, Brunner-La Rocca HP, Vogt PR, et al. Longterm follow-up in hypertrophic obstructive cardiomyopathy after septal myectomy. Ann Thorac Surg 1998;65:1207-14.

117. Desai MY, Bhonsale A, Smedira NG, et al. Predictors of longterm outcomes in symptomatic hypertrophic obstructive cardiomyopathy patients undergoing surgical relief of left ventricular outflow tract obstruction. Circulation 2013;128:209-16.

118. Faber L, Welge D, Fassbender D, et al. One-year follow-up of percutaneous septal ablation for symptomatic hypertrophic obstructive cardiomyopathy in 312 patients: predictors of hemodynamic and clinical response. Clin Res Cardiol 2007:96:864-73.

119. Sorajja P, Valeti U, Nishimura RA, et al. Outcome of alcohol septal ablation for obstructive hypertrophic cardiomyopathy. Circulation 2008;118:131-9.

120. Maron BJ, Nishimura RA, McKenna WJ, et al. Assessment of permanent dual-chamber pacing as a treatment for drugrefractory symptomatic patients with obstructive hypertrophic cardiomyopathy. A randomized, double-blind, crossover study (M-PATHY). Circulation 1999;99:2927-33.

121. Mickelsen S, Bathina M, Hsu P, et al. Doppler evaluation of the descending aorta in patients with hypertrophic cardiomyopathy: potential for assessing the functional significance of outflow tract gradients and for optimizing pacemaker function. J Interv Card Electrophysiol 2004;11:47-53.

122. Glikson M, Gurevitz O, Yaacobi E, et al. Multiple adverse events with a dual chamber pacemaker. Pacing Clin Electrophysiol 2000;23:1010-3.

123. Thomas F, Rader F, Siegel RJ. The use of MitraClip for symptomatic patients with hypertrophic obstructive cardiomyopathy. Cardiology 137:58-61.

124. Long A, Mahoney P. Use of MitraClip to target obstructive SAM in severe diffuse-type hypertrophic cardiomyopathy: Case report and review of literature. J Invasive Cardiol 2020;32:E228-32.

125. Rowin EJ, Maron BJ, Abt P, et al. Impact of advanced therapies for improving survival to heart transplant in patients with hypertrophic cardiomyopathy. Am J Cardiol 2018;121:986-96.

126. Maron BJ, Rowin EJ, Casey SA, et al. Hypertrophic cardiomyopathy in adulthood associated with low cardiovascular mortality with contemporary management strategies. J Am Coll Cardiol 2015;65:1915-28.

127. Syed IS, Ommen SR, Breen JF, Tajik AJ. Hypertrophic cardiomyopathy: identification of morphological subtypes by echocardiography and cardiac magnetic resonance imaging. JACC Cardiovasc Imaging 2008;1:377-9.

128. Binder J, Ommen SR, Gersh BJ, et al. Echocardiographyguided genetic testing in hypertrophic cardiomyopathy: septal morphological features predict the presence of myofilament mutations. Mayo Clin Proc 2006;81:459-67.

129. Gardin JM, Palabrica T, Dubria S, et al. Localized basal ventricular septal hypertrophy: Prevalence, functional and clinical correlates in a population referred for echocardiography. Am J Noninvasive Cardiol 1992;6:5-8.

130. Wigle ED, Sasson Z, Henderson MA, et al. Hypertrophic cardiomyopathy. The importance of the site and the extent of hypertrophy. A review. Prog Cardiovasc Dis 1985;28:1-83.

131. Rajtar-Salwa R, Tokarek T, Dimitrow PP. Reversed septal curvature is associated with elevated troponin level in hypertrophic cardiomyopathy. Dis Markers 2020;2020:8821961.

132. Sakamoto T, Tei C, Murayama M, et al. Giant T wave inversion as a manifestation of asymmetrical apical hypertrophy (AAH) of the left ventricle. Echocardiographic and ultrasonocardiotomographic study. Jpn Heart J 1976;17:611-29.

133. Eriksson MJ, Sonnenberg B, Woo A, et al. Long-term outcome in patients with apical hypertrophic cardiomyopathy. J Am Coll Cardiol 2002;39:638-45.

134. Towe EC, Bos JM, Ommen SR, Gersh BJ, Ackerman MJ. Genotype-phenotype correlations in apical variant hypertrophic cardiomyopathy. Congenit Heart Dis 10:E139-45.

135. Cooke JC, Cotton JM, Monaghan MJ. Mid-ventricular HOCM with apical asynergy. Heart 2000;83:517.

136. Minami Y, Kajimoto K, Terajima Y, et al. Clinical implications of midventricular obstruction in patients with hypertrophic cardiomyopathy. J Am Coll Cardiol 2011;57:2346-55.

137. Inagaki N, Hayashi T, Takei $\mathrm{Y}$, et al. Clinical and genetic backgrounds of hypertrophic cardiomyopathy with mid-ventricular obstruction. J Hum Genet 2018;63:1273-6.

138. Baxi AJ, Restrepo CS, Vargas D, et al. Hypertrophic cardiomyopathy from A to Z: Genetics, pathophysiology, imaging, and management. Radiographics 2016;36:335-54.

139. Hughes SE. The pathology of hypertrophic cardiomyopathy. Histopathology 2004;44:412-27.

140. Kansal S, Roitman D, Sheffield LT. Interventricular septal thickness and left ventricular hypertrophy. An echocardiographic study. Circulation 1979;60:1058-65.

141. Elliott P, McKenna WJ. Hypertrophic cardiomyopathy. Lancet 2004;363:1881-91.

142. Kim S-H, Kim S-O, Han S, et al. Long-term comparison of apical versus asymmetric hypertrophic cardiomyopathy. Int Heart J 2013;54:207-11.

143. Hansen MW, Merchant N. MRI of hypertrophic cardiomyopathy: part I, MRI appearances. AJR Am J Roentgenol 2007; 189:1335-43.

144. Maron MS, Maron BJ, Harrigan C, et al. Hypertrophic cardiomyopathy phenotype revisited after 50 years with cardiovascular magnetic resonance. J Am Coll Cardiol 2009; 54:220-8.

145. Agarwal A, Khandheria BK, Paterick TE, et al. Myocardial mechanics in noncontiguous HCM. JACC Cardiovasc Imaging 2013;6:1216-8.

146. Jordà P, García-Álvarez A. Hypertrophic cardiomyopathy: Sudden cardiac death risk stratification in adults. Glob Cardiol Sci Pract 2018;2018:25.

147. Frey N, Luedde M, Katus HA. Mechanisms of disease: hypertrophic cardiomyopathy. Nat Rev Cardiol 2011;9:91-100.

148. Saumarez RC, Camm AJ, Panagos A, et al. Ventricular fibrillation in hypertrophic cardiomyopathy is associated with increased fractionation of paced right ventricular electrograms. Circulation 1992;86:467-74.

149. Olivotto I, Maron MS, Adabag AS, et al. Gender-related differences in the clinical presentation and outcome of hypertrophic cardiomyopathy. J Am Coll Cardiol 2005;46:480-7.

150. Frenneaux MP, Counihan PJ, Caforio AL, et al. Abnormal blood pressure response during exercise in hypertrophic cardiomyopathy. Circulation 1990;82:1995-2002.

151. Gollob MH, Blier L, Brugada R, et al. Recommendations for the use of genetic testing in the clinical evaluation of inherited cardiac arrhythmias associated with sudden cardiac death: 
Canadian Cardiovascular Society/Canadian Heart Rhythm Society joint position paper. Can J Cardiol 27:232-45.

152. Stătescu C, Enachi Ș, Ureche C, et al. Pushing the limits of medical management in HCM: A review of current pharmacological therapy options. Int J Mol Sci 2021;22:7218.

153. Ammirati E, Contri R, Coppini R, et al. Pharmacological treatment of hypertrophic cardiomyopathy: current practice and novel perspectives. Eur J Heart Fail 2016;18:1106-18.
154. Marstrand P, Han L, Day SM, et al. Hypertrophic cardiomyopathy with left ventricular systolic dysfunction: Insights from the SHaRe Registry. Circulation 2020;141: 1371-83.

155. Ho CY, Day SM, Ashley EA, et al. Genotype and lifetime burden of disease in hypertrophic cardiomyopathy: Insights from the Sarcomeric Human Cardiomyopathy Registry (SHaRe). Circulation 2018;138:1387-98. 